\title{
UCRL-TR-204874
}

\section{High-Temperature Studies of Glass Dissolution Rates Close to Saturation}

M. Zavarin, S.K. Roberts, P. Zhao, R.W. Williams, T.P. Rose, A. Rainer, and G.A. Pawloski

February 2004 


\section{Disclaimer}

This document was prepared as an account of work sponsored by an agency of the United States Government. Neither the United States Government nor the University of California nor any of their employees, makes any warranty, express or implied, or assumes any legal liability or responsibility for the accuracy, completeness, or usefulness of any information, apparatus, product, or process disclosed, or represents that its use would not infringe privately owned rights. Reference herein to any specific commercial product, process, or service by trade name, trademark, manufacturer, or otherwise, does not necessarily constitute or imply its endorsement, recommendation, or favoring by the United States Government or the University of California. The views and opinions of authors expressed herein do not necessarily state or reflect those of the United States Government or the University of California, and shall not be used for advertising or product endorsement purposes.

\section{Auspices Statement}

This work was performed under the auspices of the U.S. Department of Energy by University of California, Lawrence Livermore National Laboratory under Contract W-7405-Eng-48.

This report has been reproduced directly from the best available copy.

Available to DOE and DOE contractors from the

Office of Scientific and Technical Information

P.O. Box 62, Oak Ridge, TN 37831

Prices available from (423) 576-8401

http://apollo.osti.gov/bridge

Available to the public from the National Technical Information Service

U.S. Department of Commerce 5285 Port Royal Rd, Springfield, VA 22161 http://www.ntis.gov/

OR

Lawrence Livermore National Laboratory Technical Information Department's Digital Library http://www.llnl.gov/library/ 


\title{
High-Temperature Studies of Glass Dissolution Rates Close to Saturation
}

\author{
Mavrik Zavarin ${ }^{1}$, Sarah K. Roberts ${ }^{1}$, Pihong Zhao ${ }^{2}$, Ross W. Williams ${ }^{2}$, \\ Timothy P. Rose ${ }^{2}$, Amanda Rainer ${ }^{1}$, and Gayle A. Pawloski ${ }^{1}$ \\ ${ }^{1}$ Geosciences and Environmental Technologies Division, \\ Energy and Environment Directorate \\ ${ }^{2}$ Chemical Biology and Nuclear Science Division, \\ Chemistry \& Material Sciences Directorate \\ Lawrence Livermore National Laboratory \\ Livermore, California
}

Prepared for the Underground Test Area Project U. S. Department of Energy National Nuclear Security Administration Nevada Site Office

Final Report

February 1, 2004 


\section{TABLE OF CONTENTS}

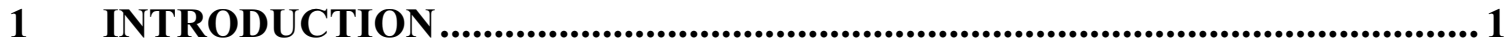

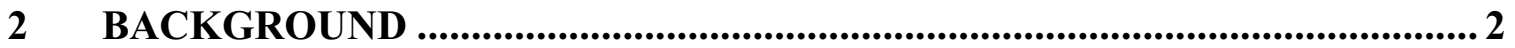

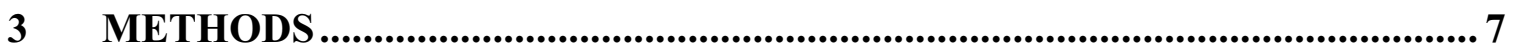

3.1 Glass Preparation ............................................................................ 7

3.1.1 Analog Glass................................................................ 7

3.1.2 Nuclear Melt Glass................................................................. 8

3.1.3 Surface Area Analysis ............................................................ 10

3.2 Buffer Solution Composition........................................................................... 10

3.3 Flow-Through Experiments .................................................................... 11

3.3.1 Analog Glass...................................................................... 11

3.3.2 Nuclear Melt Glass............................................................ 13

3.3.2.1 Uranium mixing ratios ........................................ 14

3.4 Static Analog Glass Dissolution Experiments........................................ 15

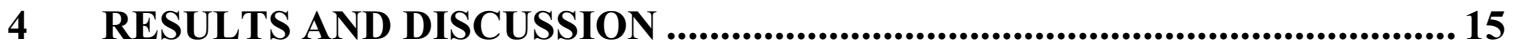

4.1 Analog Glass Dissolution .......................................................................... 15

4.2 Nuclear Melt Glass Dissolution ............................................................. 17

4.3 Modeling Glass Dissolution ........................................................................ 18

4.3.1 General Trends in Glass Dissolution Data .................................. 19

4.3.2 Comparing Glass Dissolution Data to Model Predictions.................. 20

5 CONCLUSIONS AND RECOMMENDATIONS .................................... 23

6 ACKNOWLEDGEMENTS .......................................................................... 24

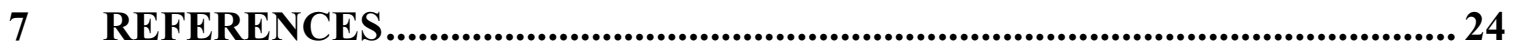

APPENDIX 1. Analytical Data from the Mo-Doped Glass Static

Dissolution Experiment at $40^{\circ} \mathrm{C}$

APPENDIX 2. Analytical Data from the Mo-Doped Glass Static Dissolution Experiment at $60^{\circ} \mathrm{C}$

APPENDIX 3. Analytical Data from the Mo-Doped Glass Static Dissolution Experiment at $80^{\circ} \mathrm{C}$

APPENDIX 4. Analytical Data from the Mo-Doped Glass Static Dissolution Experiment at $160^{\circ} \mathrm{C}$

APPENDIX 5. Analytical Data from the JMK-1 Melt Glass SPFT

Experiment at $40^{\circ}, 60^{\circ}$, and $80^{\circ} \mathrm{C}$. 
APPENDIX 6. Magnetic Sector ICP-MS Analyses of Si and U

Concentrations and ${ }^{238} \mathrm{U} /{ }^{235} \mathrm{U}$ Ratios in JMK-1 Reactor Solutions .

APPENDIX 7. Calculated Glass Dissolution for the PM-X Pre-Reactor and JMK-1 Melt Glass Samples 


\section{LIST OF FIGURES}

Figure 1. The effect of activation energy on dissolution rates as a function of temperature.

Figure 2. Effects of temperature and $\mathrm{pH}$ on dacite dissolution based on

data of Mazer (1987) and activation energy of $20 \mathrm{kcal} \mathrm{mol}^{-1}$.

Figure 3. Effect of $1 / \sigma$ on the glass dissolution rate as a function of saturation state.

Figure 4. Effect of $v$ on the glass dissolution rate as a function of saturation state.

Figure 5. Schematic of experimental set-up showing buffer solution reservoir, HPLC pump, flow-through cells in oven, and leachate collection tube.

Figure 6. Glass dissolution experimental set-up showing flow-through cell attached to shaker arm at right, pre-reactor cell at left and bubbler cell at upper left.

Figure 7. Comparison of predicted to measured glass dissolution rates. Predicted rates based on the glass dissolution rate equation used in Pawloski et al. (2001) (thin dashed lines), and rates based on the adjusted glass dissolution rate model (thick lines). Nuclear melt glass data (squares) and analog glass data (circles). $\mathrm{T}=40^{\circ} \mathrm{C}$ (black), $\mathrm{T}=60^{\circ} \mathrm{C}$ (blue), $\mathrm{T}=80^{\circ} \mathrm{C}$ (green), and $\mathrm{T}=160^{\circ} \mathrm{C}$ (red).

Figure 8. The effect of $\mathrm{Al}$ inhibition on glass dissolution rate as a function of saturation state at $40^{\circ} \mathrm{C}$ 


\section{LIST OF TABLES}

Table 1. Percent oxide composition of Mo-doped Lake County Obsidian (LCO) glass, and pre-reactor Mo-free LCO glass (based on microprobe analyses).

Table 2. Percent oxide composition of JMK-1 melt glass and PM-X prereactor glass (based on microprobe analyses).

Table 3. Gamma spectroscopy results for JMK-1 melt glass sample.

Table 4. Results of surface area analysis for glasses used in dissolution experiments.

Table 5. Uranium concentrations and isotope ratios in JMK-1 and PM-X glass samples.

Table 6. Average rates of glass dissolution based on data reported in Appendices 1-4.

Table 7. Average rates of glass dissolution based on data reported in Appendix 7. 


\section{INTRODUCTION}

Most long-lived radionuclides associated with an underground nuclear test are incorporated into a melt glass and are released by glass dissolution to become part of the hydrologic source term (HST) (Pawloski et al., 2001). Although the rates of rhyolite glass dissolution are well known under conditions where the fluid is far from saturation with respect to glass, the rates are not well known under conditions where the fluid approaches saturation. These rates are commonly much lower than the far-fromsaturation rates, often by a factor greater than 100. In recent HST simulations (Pawloski et al., 2001; Pawloski et al., 2000; Tompson et al., 1999), we conservatively estimated steady-state release rates based on a far-from-saturation fluid conditions. In recent CHESHIRE near-field simulations (Pawloski et al., 2001), it was predicted that $\sim 30 \%$ of the nuclear melt glass dissolved over 1000 years. Although the "far-from-saturation rate" approach provides a conservative estimate of glass dissolution, it may greatly overestimate the rates of melt glass dissolution. At CHESHIRE, less conservative estimates suggest that only $\sim 1 \%$ of the nuclear melt glass will dissolve in 1000 years. Lower glass dissolution rates result in lower radionuclide release rates from nuclear melt glass. The following report documents glass dissolution experiments performed to measure glass dissolution rates close to saturation.

We performed a set of glass dissolution rate measurements using single-pass flow-through (SPFT) reactors. Fluid saturation with respect to glass was controlled by adjusting the rate of fluid flow through a "pre-reactor" column packed with high-surfacearea analog nuclear melt glass. The fluid was then passed through a second reactor column with Mo-doped glass. A key aspect of these experiments was to incorporate a small amount of molybdenum in the reator glass to use as a measure of glass dissolution rate. This technique has been used successfully to measure rates of dissolution of extremely slowly reacting ceramics. Glass dissolution experiments were performed at constrained $\mathrm{pH}$ values, saturation states, and temperatures $\left(40\right.$ to $\left.80^{\circ} \mathrm{C}\right)$. In addition to SPFT experiments, a batch dissolution experiment was performed at $160^{\circ} \mathrm{C}$ to evaluate dissolution rates at higher temperatures. Carle et al. (2003) described the impact of nuclear test heat on groundwater flow. Their work suggests that resaturation of the melt glass zone may occur at temperatures as high as $250^{\circ} \mathrm{C}$. Thus, the range of temperatures examined in these experiments covers much of the anticipated range for Nevada Test Site (NTS) nuclear melt glass dissolution temperatures. ${ }^{1}$ Our glass dissolution data are compared with glass dissolution model predictions in Pawloski et al. (2001). Based on these data, adjusted glass dissolution model parameters are recommended.

In a parallel set of experiments, SPFT tests were performed with real nuclear melt glass from the NTS. These investigations used the same experimental protocol as analog experiments. However, due to extensive E\&SH requirements using radioactive samples at high temperatures/pressures, nuclear melt glass samples were examined only to $80^{\circ} \mathrm{C}$.

\footnotetext{
${ }^{1}$ Prior to nuclear melt glass resaturation, glass dissolution would not occur since water is required for glass to dissolve.
} 
Comparison of nuclear melt glass and analog glass results is used to validate our hypothesis that dissolution rates of nuclear melt glasses should be equivalent to nonradioactive analog glasses. The successful comparisons may make it operationally easier and technically defensible to use analogs instead of nuclear melt glasses in any future experiments as well as to validate the transfer of published analog glass data to nuclear melt glass dissolution models.

\section{BACKGROUND}

The glass dissolution model used in HST modeling at CHESHIRE (Pawloski et al., 2001) is based on the transition state theory (TST). Glass dissolution is defined by an equation of the following form:

$$
r=k_{0} \times e^{\frac{E_{a}}{R}\left(\frac{T-T_{0}}{T_{0} T}\right)} \times A_{s} \times \prod_{i} a_{i}^{n_{i}} \times\left(1-\left(\frac{Q}{K}\right)^{1 / \sigma}\right)^{v}+A_{s} k_{f}
$$

where $r$ is the rate of glass dissolution (mol-glass $\mathrm{g}^{-1} \mathrm{sec}^{-1}$ ), $k_{0}$ is the far-from-saturation glass dissolution rate (mol-glass $\mathrm{m}^{-2} \mathrm{sec}^{-1}$ ) at temperature $T_{0}, E_{a}$ is the activation energy (cal mol ${ }^{-1}$ ) which accounts for the change in glass dissolution as a function of temperature, $R$ is the gas constant $\left(1.99 \mathrm{cal} \mathrm{mol}^{-1} \mathrm{~K}^{-1}\right), T$ and $T_{0}$ are the temperature of interest and the reference temperature (typically $25^{\circ} \mathrm{C}$ ), respectively, $A_{s}$ is the surface area of the glass $\left(\mathrm{m}^{2} \mathrm{~g}^{-1}\right), a_{i}^{n}$ are a series of dissolution-inhibiting or -promoting solution aqueous species activities taken to some exponent $n, Q$ is the saturation of the solution relative to the solubility product of the glass $(K)$. The term $\sigma$ is related, in TST, to the stoichiometry of the rate limiting reaction step but is generally fitted empirically. The term $v$ is an empirical term often added to the dissolution/precipitation model. Finally, $k_{f}$ is the close-to-saturation term (mol-glass $\mathrm{g}^{-1} \mathrm{sec}^{-1}$ ), which is included to account for dissolution very close to saturation. In the following text, we describe how the various terms in the glass dissolution equation affect glass dissolution as a function of solution and solid composition.

The far-from-saturation glass dissolution rate, $k_{0}$, has been well documented in the literature for silicate glasses. Our glass dissolution model was based upon measurements by Mazer (1987) of basalt, dacite, and silica synthetic melt glasses at $65^{\circ} \mathrm{C}$. Based on these data, it was found that the logarithm of glass dissolution rates is linearly related to the wt.\% $\mathrm{SiO}_{2}$ in glass. The data of Mazer (1987) were used to extrapolate glass dissolution rates to the $\mathrm{SiO}_{2}$ composition of rhylolitic nuclear melt glass typically found at the NTS (77 wt.\% $\left.\mathrm{SiO}_{2}\right)$. It is believed that this glass dissolution rate constant is well known.

In the term accounting for temperature effects on dissolution (known as the Arrhenius factor), only the activation energy, $E_{a}$, is a fitted constant. Activation energies range typically from 10 to $20 \mathrm{kcal} \mathrm{mol}^{-1}$. While the choice of activation energy does not drastically affect the dissolution rate of glass at tempartures close to the reference temperature $\left(T_{0}\right.$, typically $\left.25^{\circ} \mathrm{C}\right)$, the effect is dramatic at temperatures far from the 
reference temperature. For example, at $150^{\circ} \mathrm{C}$, the range of $10-20 \mathrm{kcal} / \mathrm{mol}$ results in a $>2$ order of magnitude range in dissolution rates; at $50^{\circ} \mathrm{C}$, the same range of activation energies results in $\mathrm{a}<1$ order of magnitude range in dissolution rates (Figure 1). ${ }^{2}$ In the simulations of Pawloski et al. (2001), an activation energy of $20 \mathrm{kcal} \mathrm{mol}^{-1}$ was used.

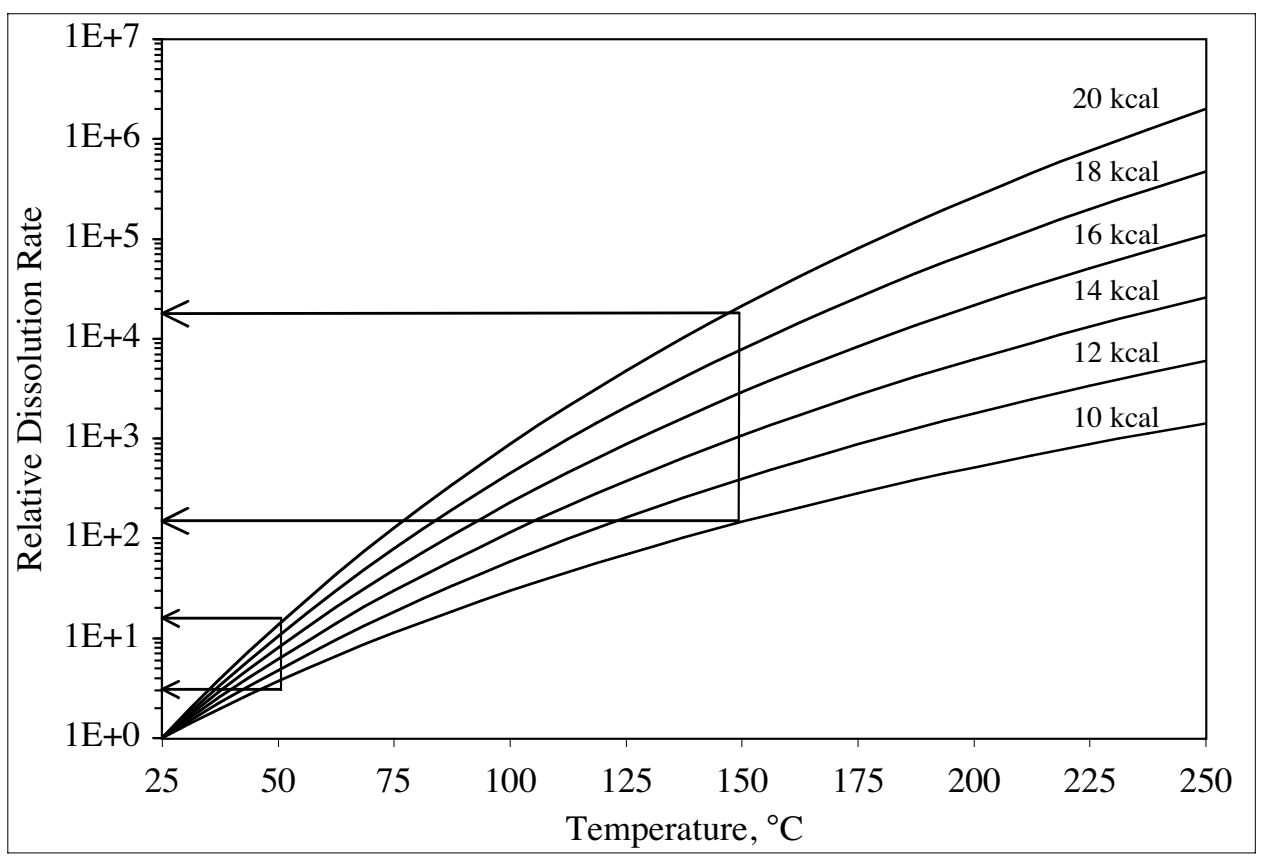

Figure 1. The effect of activation energy on dissolution rates as a function of temperature.

The rate of glass dissolution is linearly related to the reactive surface area, $A_{s}$, of the glass. The surface area of nuclear melt glasses was previously examined and estimated at 0.001 to $0.01 \mathrm{~m}^{2} / \mathrm{g}$ (Bourcier et al., 2000). Often, the effect of surface area on glass dissolution rate, $r$, is removed by dividing the rate by the reactive surface area:

$$
r^{*}=\frac{r}{A_{s}}
$$

where $r^{*}$ is in units of $\mathrm{mol} \mathrm{m}^{-2} \sec ^{-1}$. In the following discussion, we use $r^{*}$ when discussing the glass dissolution rates.

The series of dissolution-inhibiting or dissolution-promoting solution aqueous species activities, $a_{i}$, with exponents, $n_{i}$, can include a large number of components. However, the principal species that are used to account for solution composition effects on glass dissolution are $\mathrm{H}^{+}$and $\mathrm{OH}^{-}$. These two species act to promote dissolution at

${ }^{2}$ Based on the assumption that the reference temperature is $25^{\circ} \mathrm{C}$. 
high and low $\mathrm{pH}$. A plot of the effect of $\mathrm{H}^{+}$and $\mathrm{OH}^{-}$on glass dissolution as a function of $\mathrm{pH}$ and temperature for the dacite of Mazer (1987) is shown in Figure 2. Two subtle effects should be noted. First, the minimum in the rate decreases in $\mathrm{pH}$ with increasing temperature. This occurs because the $\mathrm{pH}$ of neutrality decreases with increasing temperature. Second, the $\mathrm{pH}$ range over which the neutral term of the dissolution rate equation controls the glass dissolution rate narrows with increasing temperature. In fact, the role of the neutral term becomes insignificant at high temperatures; this effect results from the increasing disproportionation of water at higher temperatures, which increases the role of the $\mathrm{H}^{+}$and $\mathrm{OH}^{-}$terms of the dissolution rate equation.

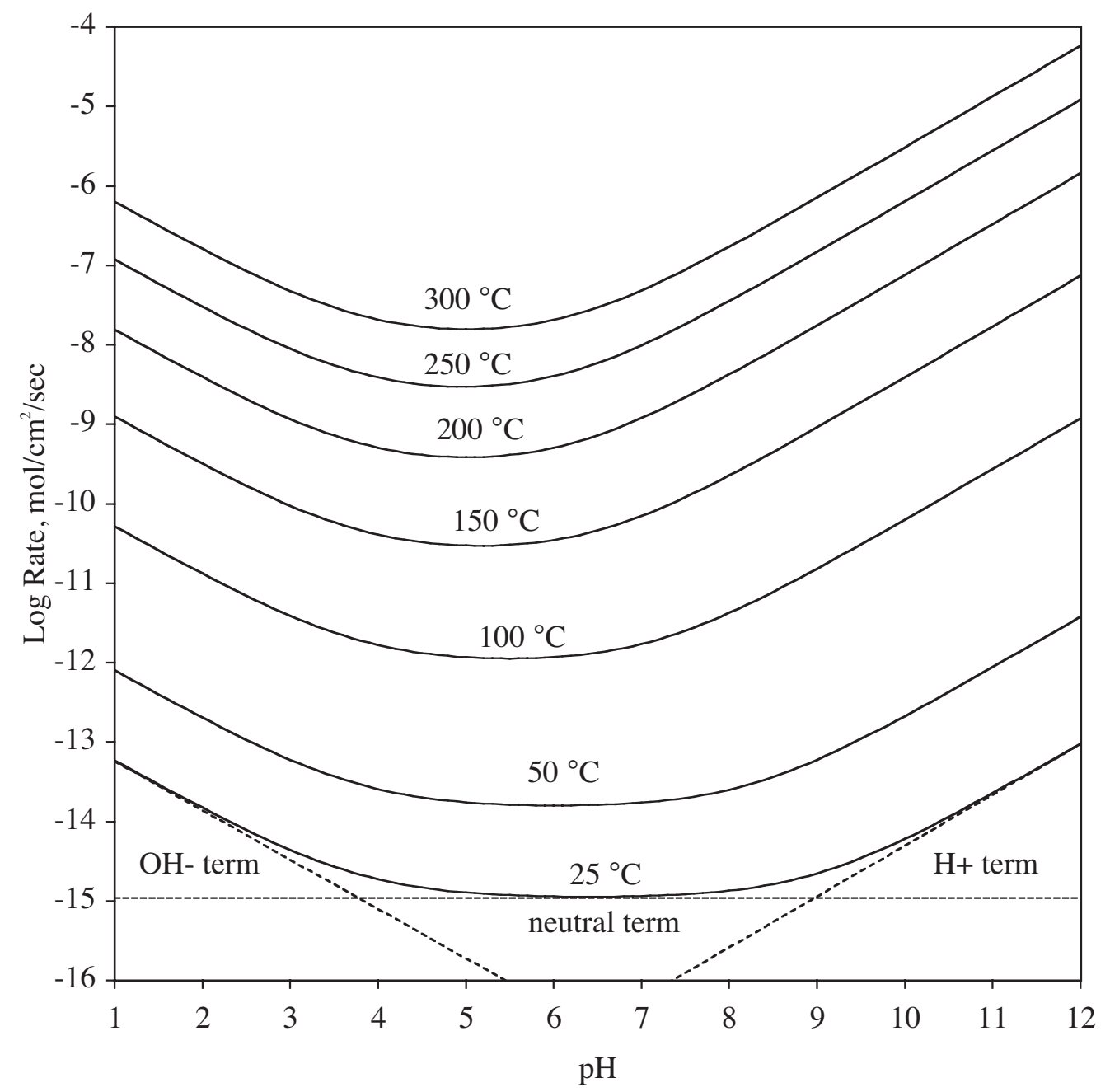

Figure 2. Effects of temperature and $\mathrm{pH}$ on dacite dissolution based on data of Mazer (1987) and activation energy of $20 \mathrm{kcal} \mathrm{mol}^{-1}$.

It should be noted that $\mathrm{H}^{+}$and $\mathrm{OH}^{-}$are not the only terms reported to have dissolution-promoting or dissolution-inhibiting effects. An element often reported in the literature to have a significant inhibitory effect on the dissolution of a variety of 
aluminosilicate minerals and glasses is $\mathrm{Al}$. The aluminum inhibition exponent at $\mathrm{pH} 2$ and $150^{\circ} \mathrm{C}$ for kaolinite $\left(n_{i}\right)$ was estimated at -1 . For albite at $\mathrm{pH} 9$ and $150^{\circ} \mathrm{C}$, the exponent $n_{i}$ was estimated at -0.33 (Oelkers et al., 1994). The potential effect of aluminum inhibition will be discussed later in this report.

The saturation term, $1-Q / K$, along with its exponents, $\sigma$ and $v$, is a complicated term with a number of empirically fitted parameters. For glasses, the term $K$ has been defined by the solubility product of amorphous silica while $Q$ was defined as the activity of $\mathrm{SiO}_{2}$ (aq) (Pawloski et al., 2001). As such, the saturation state of the solution $(Q / K)$ is assumed to be controlled entirely by the activity of $\mathrm{SiO}_{2}(\mathrm{aq})$ in solution. This may not necessarily be the case but is assumed to be a reasonable approximation in this report. The effect of the two exponential terms, $\sigma$ and $v$, is quite different and is shown in Figures 3 and 4 . The effect of the $1 / \sigma$ term is to reduce the glass dissolution rate drastically even when the solution is relatively undersaturated. ${ }^{3}$ In fact, as $\sigma$ is increased, it appears that the shape of the glass dissolution rate as a function of saturation state does not change but is simply shifted to a lower dissolution rate. This is in contrast to the $v$ term (Figure 4), which tends not to significantly affect the dissolution rate far from saturation but greatly reduces the dissolution rate as saturation is approached. ${ }^{4}$ Under ambient solution conditions at the NTS where the saturation term, $1-Q / K$, is equal to 0.7 , the $v$ term is less likely to significantly reduce glass dissolution rates than the $1 / \sigma$ term. Later in this report, we evaluate both these terms with regards to fitting our glass dissolution experiment data.

The saturation term, $k_{f}$, provides a means to continue the dissolution of glass even if saturation with respect to amorphous silica has been reached. This term accounts for the fact that glass is inherently unstable and will continue to dissolve to form more stable precipitates even under saturated conditions. ${ }^{5}$ The close-to-saturation rate is, however, typically orders of magnitude lower than the far-from-saturation rate. Thus, the saturation rate affects the rate of glass dissolution only under conditions of high saturation. As will be discussed later in this report, glass dissolution in our experiments was slow enough such that an approach to high saturation was not achieved. Thus, this close-to-saturation term has not been measured. The rate of dissolution slows quickly enough at intermediate levels of saturation such that an approach to saturation is difficult to achieve.

\footnotetext{
${ }^{3}$ Boucier et al. (1994) reported that the $1 / \sigma$ for their glass dissolution experiments was 0.1 .

${ }^{4}$ For calcite, this term has been reported to be approximately 3 (Bourcier et al., 1994).

${ }^{5}$ Note that saturation is defined based on amorphous silica solubility.
} 


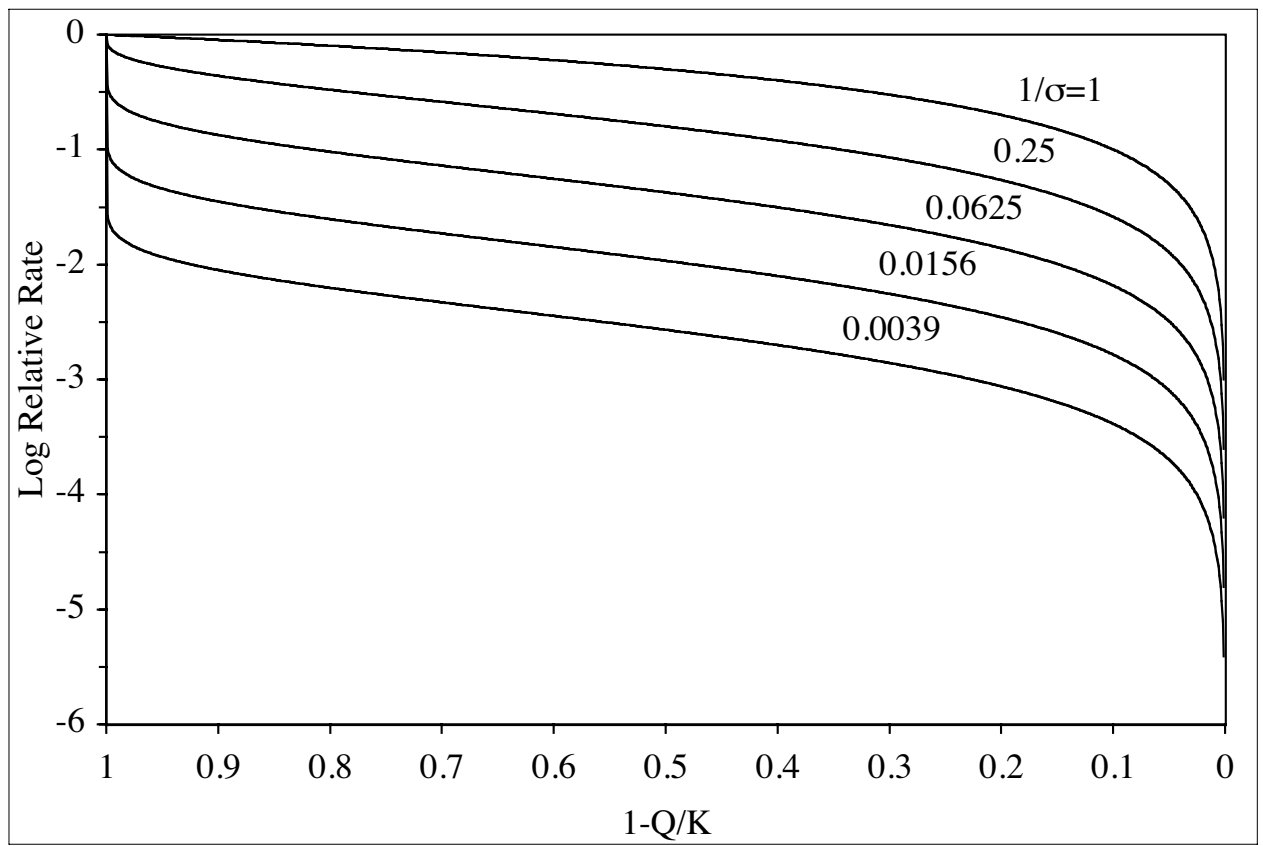

Figure 3. Effect of $1 / \sigma$ on the glass dissolution rate as a function of saturation state.

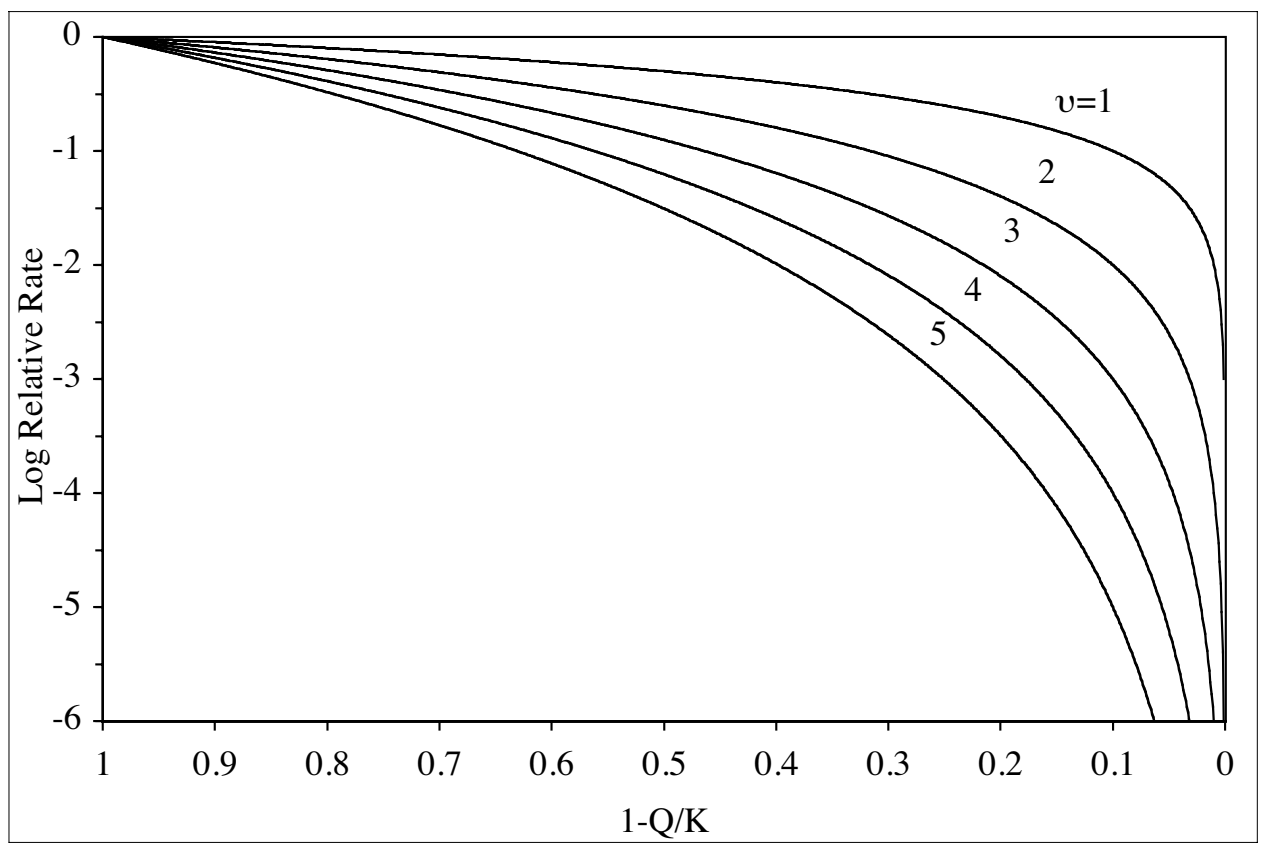

Figure 4. Effect of $v$ on the glass dissolution rate as a function of saturation state. 


\section{METHODS}

\subsection{Glass Preparation}

\subsubsection{Analog Glass}

Two glasses were prepared for "near saturation" single-pass flow-through (SPFT) experiments: a Mo-free Lake County Obsidian (LCO) and a LCO doped with $\mathrm{MoO}_{3}$. One-weight-percent $\mathrm{MoO}_{3}$ was used to minimize the potential for Mo to affect the dissolution rate behavior of the glass while maximizing the potential to detect Mo at low glass dissolution rates. The technique has been used successfully to measure rates of dissolution of extremely slowly reacting ceramics. The preparation method for each glass is described below, and an electron probe analysis of the Mo-doped and Mo-free LCO glass is given in Table 1.

For the Mo-free LCO glass, approximately $450 \mathrm{~g}$ of LCO was placed in a single large platinum crucible and fused in air at $1400^{\circ} \mathrm{C}$ for 24 hours. At the end of the fusion, the furnace temperature was adjusted to $750^{\circ} \mathrm{C}$, and the sample was annealed for 164 hours at that temperature.

For the Mo-doped LCO glass, approximately $450 \mathrm{~g}$ of LCO was fused for 2 hours at $1200^{\circ} \mathrm{C}$ to dehydrate the sample prior to addition of $\mathrm{MoO}_{3}$. The dehydrated glass was then run through a tungsten carbide shatterbox and passed through a $125-\mu \mathrm{m}$ sieve. $\mathrm{MoO}_{3}$ was then added to aliquots of the sample in an amount calculated to yield $1 \mathrm{wt} . \%$ $\mathrm{MoO}_{3}$ in the final product. All of the aliquots were then put in a polyethylene bottle and mixed by hand. The mixture was then placed in a single large platinum crucible and the sample fused in air at $1400^{\circ} \mathrm{C}$ for 24 hours. The furnace was then cooled to $1000^{\circ} \mathrm{C}$, the sample removed from the furnace and quenched in water. Examination in transmitted light did not reveal any remaining un-dissolved $\mathrm{MoO}_{3}$ or other crystalline phases. The resulting Mo-doped glass was then crushed, sieved and fused 2 more times. The second fusion was for 24 hours, the third for 66 hours. At the end of the third fusion, the sample was quenched in water and then returned to the furnace at $750^{\circ} \mathrm{C}$ for 246 hours to anneal. The water quench cracked the glass, facilitating removal from the crucible.

An aliquot of each sample was mounted in epoxy for electron probe analysis. The samples were analyzed at $15 \mathrm{kV}$, with a beam current of $10 \mathrm{nA}$ and a beam diameter of $10 \mu \mathrm{m}$. The analytical precision of a single $\mathrm{MoO}_{3}$ analysis is $\sim 5 \%$. The average $\mathrm{MoO}_{3}$ content for 30 point analyses of the Mo-doped LCO is $0.91 \mathrm{wt} . \%$ with a standard deviation of 0.05 (Table 1). As such, the sample is homogeneous at the $2 \sigma$ level, and further crushing-fusion cycles are unlikely to significantly improve sample homogeneity. The low analytical totals suggest that the sample was slightly damaged by the electron beam. No $\mathrm{MoO}_{3}$ was detected in the Mo-free LCO.

After preparation, the glasses were crushed, sieved, rinsed repeatedly in alcohol and distilled water, and the 25-53 $\mu \mathrm{m}$ grain size collected for the SPFT tests. 
Table 1. Percent oxide composition of Mo-doped Lake County Obsidian (LCO) glass, and pre-reactor Mo-free LCO glass (based on microprobe analyses).

\begin{tabular}{ccc}
\hline Oxide & Mo-doped LCO & Mo-free LCO \\
\hline $\mathrm{SiO}_{2}$ & 74.05 & 76.01 \\
$\mathrm{Al}_{2} \mathrm{O}_{3}$ & 12.67 & 13.00 \\
$\mathrm{FeO}$ & 0.75 & 0.70 \\
$\mathrm{MnO}$ & 0.07 & 0.08 \\
$\mathrm{MgO}$ & 0.11 & 0.09 \\
$\mathrm{CaO}$ & 0.83 & 0.52 \\
$\mathrm{Na} \mathrm{O}_{2} \mathrm{O}$ & 2.95 & 3.65 \\
$\mathrm{~K}_{2} \mathrm{O}$ & 4.32 & 4.81 \\
$\mathrm{MoO}_{3}$ & 0.91 & -- \\
$\mathrm{TiO}_{2}$ & -- & 0.11 \\
\hline Total & $\mathbf{9 6 . 6 6}$ & $\mathbf{9 8 . 9 7}$ \\
\hline
\end{tabular}

\subsubsection{Nuclear Melt Glass}

The nuclear melt glass sample (JMK-1) used in the experiments is from an undisclosed underground test that was detonated below the water table on Pahute Mesa. The sample consists of highly vesicular, colorless- to gray-banded glass, similar in appearance to pumice. Archival drill cuttings of pre-shot volcanic tuff were also obtained from the working point of the same test. The tuff was expected to have a bulk chemical composition similar to the melt glass (compositional similarity was later confirmed, Table 2), and could therefore be used in the pre-reactor cell of the dissolution apparatus. The volcanic tuff was crushed to -150 mesh size $(<0.1 \mathrm{~mm})$, melted at $1450^{\circ} \mathrm{C}$ in air, and then quenched to produce a homogeneous, non-radioactive "pre-reactor glass."

The major element compositions of the nuclear melt glass and pre-reactor glass samples were analyzed on a JEOL 8200 electron microprobe using a 7.5-nA, 15-keV electron beam defocused to a diameter of $30 \mu \mathrm{m}$. X-ray intensities were converted to element concentrations using a CITZAF algorithm. Reference standards included a variety of silicate and oxide minerals. Each sample was analyzed at 10 randomly selected spots. Compositional averages are reported in Table 2 as oxide weight percent. The results show that the melt glass and pre-reactor glass samples have very similar major element compositions. Hence, the pre-reactor glass is well suited for producing a solution that is close to chemical equilibrium with the melt glass sample. The data indicate that the working point lithology for this test was a high-silica rhyolite. 
Table 2. Percent oxide composition of JMK-1 melt glass and PM-X pre-reactor glass (based on microprobe analyses).

\begin{tabular}{ccc}
\hline Oxide & \multicolumn{2}{c}{ JMK-1 } \\
\cline { 2 - 3 } & \multicolumn{2}{c}{ Weight percent } \\
\hline $\mathrm{SiO}_{2}$ & 77.25 & 77.63 \\
$\mathrm{TiO}_{2}$ & 0.07 & 0.08 \\
$\mathrm{Al}_{2} \mathrm{O}_{3}$ & 12.56 & 12.52 \\
$\mathrm{FeO}$ & 0.79 & 0.66 \\
$\mathrm{MnO}$ & 0.00 & 0.02 \\
$\mathrm{MgO}$ & 0.08 & 0.02 \\
$\mathrm{CaO}$ & 0.61 & 0.73 \\
$\mathrm{Na} O$ & 3.25 & 3.59 \\
$\mathrm{~K}_{2} \mathrm{O}$ & 5.22 & 4.73 \\
\hline Total & $\mathbf{9 9 . 8 3}$ & $\mathbf{9 9 . 9 8}$ \\
\hline
\end{tabular}

Activities and concentrations of gamma-emitting radionuclides were measured in the melt glass sample using a fixed $\mathrm{Ge}(\mathrm{Li})$ detector. The total count time was 1 day. Gamma spectra were obtained for ${ }^{60} \mathrm{Co},{ }^{137} \mathrm{Cs},{ }^{152} \mathrm{Eu},{ }^{154} \mathrm{Eu},{ }^{155} \mathrm{Eu}$, and ${ }^{241} \mathrm{Am}$ (Table 3), and reported values reflect activities at the time of data acquisition (31 January 2002). The data reveal that the melt glass is from one of the more recent NTS underground tests (probably $<20$ years old) as indicated by the readily detectable amounts of fission products with half-lives on the order of 5 to 10 years.

The glass samples were crushed and sieved to obtain particle sizes of 25-53 $\mu \mathrm{m}$ (melt glass) and 25-74 $\mu \mathrm{m}$ (pre-reactor glass). Particles with diameters of $<25 \mu \mathrm{m}$ were removed from the sieved material by washing the glass in water followed by acetone.

Table 3. Gamma spectroscopy results for JMK-1 melt glass sample.

\begin{tabular}{cccc}
\hline Isotope & $\begin{array}{c}\text { Half-life } \\
\text { (years) }\end{array}$ & $\begin{array}{c}\text { Concentration } \\
\text { (atoms/g) }\end{array}$ & $\begin{array}{c}\gamma \text {-activity } \\
\text { (dpm/g) }\end{array}$ \\
\hline${ }^{60} \mathrm{Co}$ & 5.27 & $3.3 \times 10^{9}$ & $8.3 \times 10^{2}$ \\
${ }^{137} \mathrm{Cs}$ & 30.2 & $1.7 \times 10^{12}$ & $7.4 \times 10^{4}$ \\
${ }^{152} \mathrm{Eu}$ & 13.5 & $2.1 \times 10^{10}$ & $2.1 \times 10^{3}$ \\
${ }^{154} \mathrm{Eu}$ & 8.59 & $3.9 \times 10^{9}$ & $5.9 \times 10^{2}$ \\
${ }^{155} \mathrm{Eu}$ & 4.71 & $1.3 \times 10^{9}$ & $3.7 \times 10^{2}$ \\
${ }^{241} \mathrm{Am}$ & 433 & $1.9 \times 10^{12}$ & $5.7 \times 10^{3}$ \\
\hline
\end{tabular}




\subsubsection{Surface Area Analysis}

The surface area of the glasses was measured by BET (Brunauer et al., 1938) using a Micromeritics Gemini II 2370 surface area analyzer. Results are listed in Table 4. All samples were outgassed at $110^{\circ} \mathrm{C}$; nitrogen gas was used to outgas the nonradioactive samples, and JMK-1 melt glass was outgassed under vacuum.

Importantly, the glass surface areas reported in Table 4 cannot be compared to whole-rock effective reactive surface area measurements reported by Bourcier et al. (2000) or the specific surface area measurements of Papelis et al. (2000) because they do not reflect the surface areas of pristine non-crushed natural glasses. Glass samples listed in Table 4 were prepared by crushing and sieving the glass $(25-53$ or $25-74 \mu \mathrm{m}$ particles) to provide a uniform glass particle size. The specific surface area of these samples approaches the expected surface area based on non-porous smooth spheres within the sieved particle size range $\left(0.1\right.$ to $\left.0.03 \mathrm{~m}^{2} / \mathrm{g}\right){ }^{6}$ However, it is slightly higher than the expected surface area due to entrainement of smaller particles, as can be seen in SEM photos taken of the nuclear melt glass (Zavarin et al., 2004).

Table 4. Results of surface area analysis for glasses used in dissolution experiments.

\begin{tabular}{lc}
\hline Sample name/number & $\begin{array}{c}\text { Surface area } \\
\left(\mathrm{m}^{2} / \mathrm{g}\right)\end{array}$ \\
\hline Mo-doped-LCO glass & 0.1901 \\
LCO pre-reactor glass & 0.1972 \\
JMK-1 melt glass & 0.2969 \\
PM-X pre-reactor glass & 0.2329 \\
\hline
\end{tabular}

\subsection{Buffer Solution Composition}

All SPFT tests were performed using $1 \mathrm{mM} \mathrm{NaHCO}_{3}$ flow through solution. The $\mathrm{pH}$ of the starting solution was $\sim 8.5$. This solution is similar in composition to the lowsodium carbonate waters found at NTS. In certain analog flow-through experiments, $\mathrm{SiO}_{2}$ (aq) was added to the flow-through solutions to increase the saturation state with respect to amorphous silica. In those cases, the $\mathrm{SiO}_{2}(\mathrm{aq})$ concentration in solution was $\sim 100 \mathrm{mg} / \mathrm{L}$, the $\mathrm{NaHCO}_{3}$ concentration was $1 \mathrm{mM}$, and some nitric acid was used to adjust the $\mathrm{pH}$ to 8.5 .

\footnotetext{
${ }^{6}$ Papelis et al. (2000) noted that surface areas of material with particles sizes near $10 \mu \mathrm{m}$ approached the expected surface area based on non-porous smooth spheres in their analog glass samples.
} 


\subsection{Flow-Through Experiments}

\subsubsection{Analog Glass}

Three sets of flow-through experiments to measure glass dissolution rates were performed $\left(40^{\circ} \mathrm{C}, 60^{\circ} \mathrm{C}\right.$, and $\left.80^{\circ} \mathrm{C}\right)$. The experimental system consisted of various components that allowed filtered $(0.2 \mu \mathrm{m})$ solutions to flow through cells containing glass and exit into leachate receivers (Figure 5). Flow rate and $\mathrm{pH}$ could be fixed and monitored as a function of time, and their effects on glass dissolution could be observed and quantified from analysis of leachate. Gentle rocking during sampling kept the glasses suspended, and allowed the system to behave as a continuously stirred reactor. To ensure that solutions in the flow-through cell approached saturation with respect to silica, a pre-reactor cell was placed in line before the flow-through cell. This pre-reactor consisted of a large flow-through cell that was packed with crushed glass. A debubbler cell, which allows gas (primarily $\mathrm{CO}_{2}[\mathrm{~g}]$ ) to exsolve during heating and escape, was placed in-line for each experiment. The experimental system (except the HPLC pump) was placed in an oven to regulate the temperature. Temperature was monitored by a thermocouple.

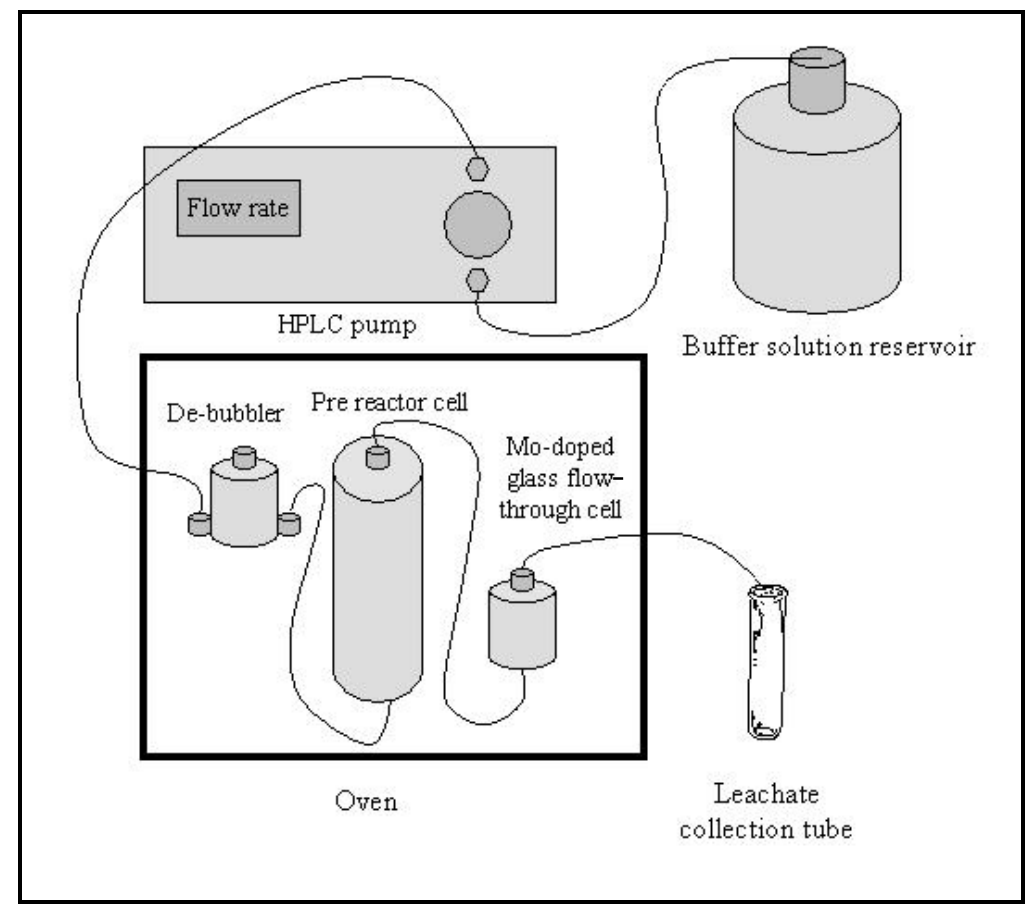

Figure 5. Schematic of experimental set-up showing buffer solution reservoir, HPLC pump, flow-through cells in oven, and leachate collection tube. 
A schematic of the experimental set-up is shown in Figure 5, and a photograph of the debubbler and flow-through cells in the oven is shown in Figure 6. At each temperature $\left(40^{\circ} \mathrm{C}, 60^{\circ} \mathrm{C}\right.$, and $\left.80^{\circ} \mathrm{C}\right)$, solution flow rates of $0.01 \mathrm{~mL} / \mathrm{min}, 0.1 \mathrm{~mL} / \mathrm{min}$, and $1.0 \mathrm{~mL} / \mathrm{min}$ were used. The pore volume of the system was determined by calculating the volumes of the tubing and the reactor cells. We assumed that dissolution of the glass was close to steady state at time of sampling because at each flow rate, an amount equal to several pore volumes of solution was flowed through the cells before leachate samples were collected for analysis. Also, at each flow rate and temperature, several samples were taken to ensure that a steady state had been reached.

Leachate was collected, acidified, and analyzed by ICP-MS for molybdenum, and on ICP-AES for aluminum, calcium, potassium, magnesium, sodium, and silica. All analytical results are listed in Appendices 1-3. The $\mathrm{pH}$ was also measured; the $\mathrm{pH}$ varied only slightly during these experiments.

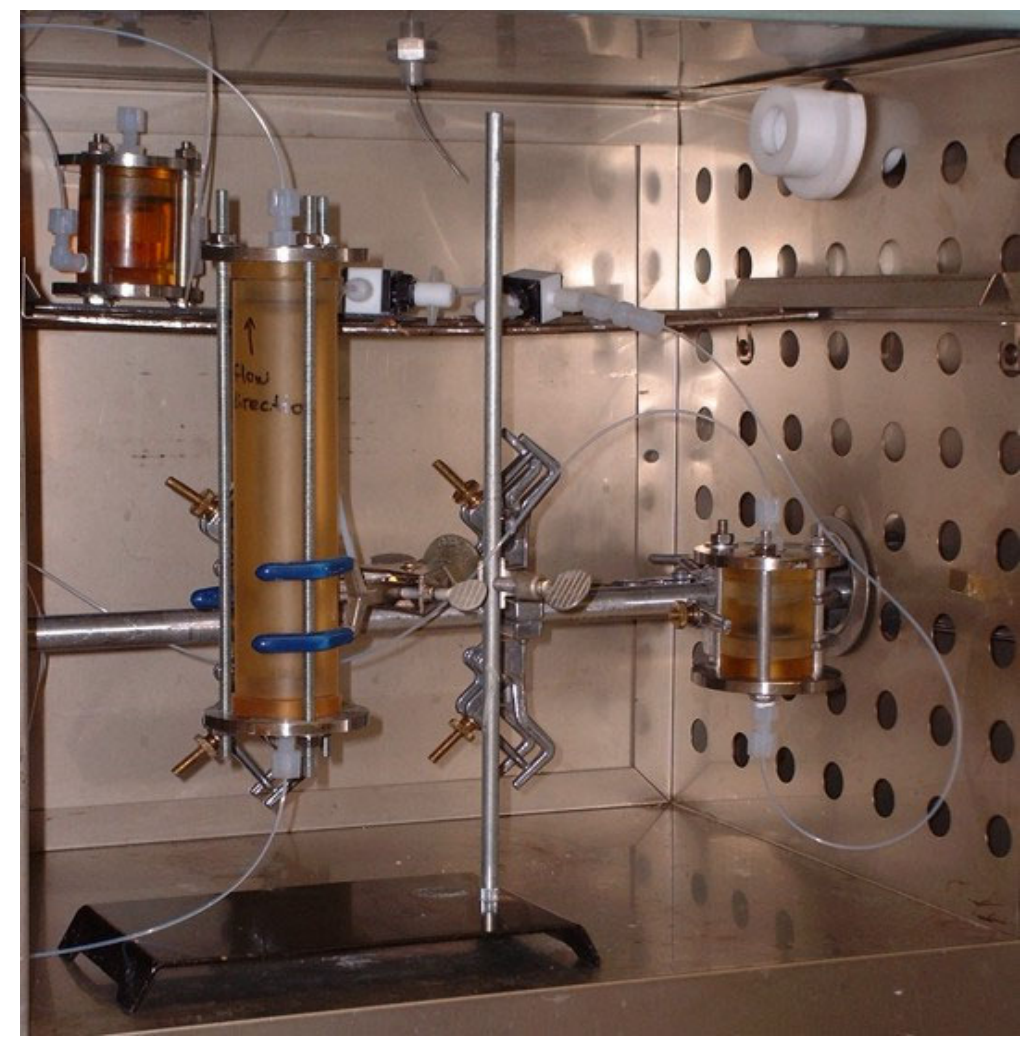

Figure 6. Glass dissolution experimental set-up showing flow-through cell attached to shaker arm at right, prereactor cell at left and bubbler cell at upper left. 


\subsubsection{Nuclear Melt Glass}

Nuclear melt glass dissolution experiments were run using a two-cell flowthrough reactor similar to that used in analog glass dissolution experiments. The prereactor cell is used to raise the silica concentration in solution to near saturation before introducing the solution to the nuclear melt glass. This approach approximates natural fluid conditions expected near the melt glass of underground nuclear tests. A dilute $(1 \mathrm{mM})$ sodium bicarbonate solution was passed through the cells at a rate of $\sim 14$ to $16 \mathrm{~mL} /$ day, and at temperatures of $40^{\circ} \mathrm{C}, 60^{\circ} \mathrm{C}$, or $80^{\circ} \mathrm{C}$.

The key technical challenge in the nuclear melt glass experiments was to identify a unique trace element or isotope present only in the melt glass that could be used to monitor dissolution rates. Using a pre-reactor glass that was compositionally very similar to the melt glass was advantageous in terms of simulating natural dissolution conditions. However, since both samples were from the same source rock, both had nearly identical trace element abundances. This effectively limited the choice of monitoring species to test-derived radionuclides. ${ }^{137} \mathrm{Cs}$ is present at fairly high concentrations in the melt glass (Table 3), but preliminary leaching rate estimates indicated that the concentration going into solution would be too low to detect by gamma counting. Moreover, the ${ }^{137} \mathrm{Cs}$ could not be measured on a magnetic sector ICP-MS because of a strong isobaric interference with ${ }^{137} \mathrm{Ba}$. After careful consideration of all the options, it was determined that uranium isotopes (in particular, ${ }^{238} \mathrm{U} /{ }^{235} \mathrm{U}$ ratios) were the best choice for a dissolution monitor. This decision was guided in part by our ability to accurately measure extremely low uranium abundances (less than 1 part per trillion) on the magnetic sector ICP-MS. In addition, uranium tends to be conservative in aqueous bicarbonate solutions due to its tendency to form soluble uranyl carbonate complexes under slightly alkaline $\mathrm{pH}$ conditions (e.g. Langmuir, 1978). However, this choice still depended upon whether the ${ }^{238} \mathrm{U} /{ }^{235} \mathrm{U}$ ratio in the melt glass was sufficiently different from the natural abundance in the pre-reactor glass, so that the melt glass uranium contribution could be reliably detected at very low levels in solution.

Small (0.3 g) samples of melt glass and pre-reactor glass were each dissolved in strong $\mathrm{HNO}_{3}, \mathrm{HF}$, and $\mathrm{HClO}_{4}$, evaporated to dryness, and then brought back into solution in dilute $\mathrm{HNO}_{3}$. These samples were then analyzed by ICP-MS to determine their uranium concentrations and isotope ratios. The results are given in Table 5. The uranium concentrations in both glasses are similar, but their ${ }^{238} \mathrm{U} /{ }^{235} \mathrm{U}$ ratios are quite distinct. Whereas the pre-reactor glass has a natural uranium isotope ratio, the melt glass shows a strong enrichment in ${ }^{235} \mathrm{U}$ from the nuclear test. Hence, monitoring variations in dissolved ${ }^{238} \mathrm{U} /{ }^{235} \mathrm{U}$ ratios during the experiments could provide a means of estimating glass dissolution rates. 
Table 5. Uranium concentrations and isotope ratios in JMK-1 and PM-X glass samples.

\begin{tabular}{lcc}
\hline \multicolumn{1}{c}{ Sample } & $\begin{array}{c}\mathrm{U} \\
(\mathrm{ppb})\end{array}$ & ${ }^{238} \mathrm{U} /{ }^{235} \mathrm{U}$ \\
\hline JMK-1 melt glass & $4637.4 \pm 8.8$ & 14.14 \\
PM-X Pre-reactor glass & $4447.8 \pm 9.0$ & 136.97 \\
\hline
\end{tabular}

\subsubsection{Uranium mixing ratios}

The uranium concentration and isotope ratio in the solution exiting the flow through reactor represents a mixture of uranium dissolved from the pre-reactor glass and the nuclear melt glass. The relative proportions of uranium from these two sources can be determined by standard isotope dilution calculations (Moore et al., 1973), which are summarized in Faure (1986).

Let $N=$ the number of atoms of natural uranium (from the pre-reactor glass), $S=$ the number of atoms of "spike" uranium (from the nuclear melt glass), and $R_{\mathrm{m}}=$ the measured ${ }^{238} \mathrm{U} /{ }^{235} \mathrm{U}$ ratio of the mixture. For our experiment, we can write the expression:

$$
R_{m}=\frac{0.9928 N+0.93395 S}{0.0072 N+0.06605 S}
$$

where: $0.9928=$ the natural ${ }^{238} \mathrm{U}$ abundance in the pre-reactor glass

$0.93395=$ the ${ }^{238} \mathrm{U}$ abundance in the melt glass

$0.0072=$ the natural ${ }^{235} \mathrm{U}$ abundance in the pre-reactor glass, and

$0.06605=$ the ${ }^{235} \mathrm{U}$ abundance in the melt glass.

Next we convert to weights of $N$ and $S$ by dividing by Avogadro's number (A) and multiplying by the respective atomic weights of uranium in each glass

$$
\begin{aligned}
& N_{\mathrm{w}}=238.0291 * N / \mathrm{A} \\
& S_{\mathrm{w}}=237.8522 * S / \mathrm{A}
\end{aligned}
$$

where $N_{\mathrm{w}}=$ the weight of uranium in the pre-reactor glass, and $S_{\mathrm{w}}=$ the weight of uranium in the melt glass. It follows that the measured weight of the mixture $\left(W_{\mathrm{m}}\right)$ is defined as

$$
W_{\mathrm{m}}=N_{\mathrm{w}}+S_{\mathrm{w}}
$$


Solving (2) and (3) for $N$ and $S$, respectively, substituting these expressions into equation (1), and solving for $N_{\mathrm{w}}$ yields the following equation

$$
N_{w}=S_{w}\left[\frac{238.0291}{237.8522}\right]\left[\frac{0.93395-R_{m}(0.06605)}{R_{m}(0.0072)-0.9928}\right]=S_{w} Q
$$

Next we substitute $S_{\mathrm{w}}=W_{\mathrm{m}}-N_{\mathrm{w}}$ into equation (5) to obtain the final expression for $N_{\mathrm{w}}$

$$
\begin{gathered}
N_{\mathrm{w}}=\left(W_{\mathrm{m}}-N_{\mathrm{w}}\right)[\mathrm{Q}] \\
N_{\mathrm{w}}+N_{\mathrm{w}}[\mathrm{Q}]=W_{\mathrm{m}}[\mathrm{Q}] \\
N_{\mathrm{w}}(1+[\mathrm{Q}])=W_{\mathrm{m}}[\mathrm{Q}] \\
N_{w}=\frac{W_{m}[Q]}{(1+[Q])}
\end{gathered}
$$

In practice, $W_{\mathrm{m}}$ and $R_{\mathrm{m}}$ represents the $\mathrm{U}$ concentration and ${ }^{238} \mathrm{U} /{ }^{235} \mathrm{U}$ ratio of the flow through reactor solution, measured by the magnetic sector ICP-MS. The relative proportion of the total $\mathrm{U}$ concentration from the pre-reactor glass $\left(N_{\mathrm{w}}\right)$ and the melt glass $\left(S_{\mathrm{w}}\right)$ are then calculated from equations (6) and (4), respectively. These data can then be used to calculate glass dissolution rates.

\subsection{Static Analog Glass Dissolution Experiments}

Due to temperature limitations of the SPFT cells, a static, higher temperature experiment was performed at $160^{\circ} \mathrm{C}$ in a titanium Parr-bomb apparatus. Ten grams of the Mo-doped glass was reacted with $100 \mathrm{~mL}$ of $1 \mathrm{mM} \mathrm{NaHCO}_{3}$ in a Parr-bomb apparatus equipped with a sampling port. Solutions from this static experiment were sampled daily over a period of a week and analyzed for the same elements as the flow-through experiments. Each sampling took $\sim 10 \mathrm{~mL}$ solution from the reactor; the first $5 \mathrm{~mL}$ were discarded to ensure that the sampling port was flushed of old solution.

\section{RESULTS AND DISCUSSION}

\subsection{Analog Glass Dissolution}

Raw data for the SPFT analog glass dissolution experiments are listed in Appendices 1, 2, and 3. Data from the $160^{\circ} \mathrm{C}$ static dissolution experiment are listed in Appendix 4.

Glass dissolution rates were calculated based on Mo concentrations in the fluid exiting the flow-through cells. The following equation was used: 


$$
r^{*}=[M o] \times \frac{m o l_{\text {glass }}}{m o l_{M o}} \times g_{\text {Mo-glass }}^{-1} \times\left(\frac{m^{2}}{g_{\text {Mo-glass }}}\right)^{-1} \times \frac{m L}{\min .} \times \frac{0.001 L}{m L} \times \frac{1 \mathrm{~min} .}{60 \mathrm{sec}}
$$

Based on the electron microprobe data, the ratio of mol glass to mol Mo is 153. For all flow-through experiments, the same mass of Mo-glass $(1.8057 \mathrm{~g})$ and surface area $\left(0.1901 \mathrm{~m}^{2} / \mathrm{g}\right)$ was used. Thus, the rate of glass dissolution could be calculated simply by multiplying the flow rate and the concentration of Mo $(\mathrm{mol} / \mathrm{L})$ by $7.43 \times 10^{-3}$. Based on these calculations, average dissolution rates were calculated for each temperature and flow condition. The results are listed in Table 6. Standard deviations are quite small indicating that reaction rates reached steady state in all experiments.

For the $160^{\circ} \mathrm{C}$ Parr bomb experiments, rates were based on the change in Mo concentration between sampling time intervals in the following manner:

$$
r^{*}=\frac{[M o]_{2}-[M o]_{1}}{t_{2}-t_{1}} \times \frac{\text { mol }_{\text {glass }}}{\text { mol }_{\text {Mo }}} \times g_{\text {Mo-glass }}^{-1} \times\left(\frac{m^{2}}{g_{\text {Mo-glass }}}\right) \times \text { Vol }_{\cdot 1}
$$

where $t$ is in seconds and Vol. is the volume of solution in the Parr bomb over that particular time interval (liters). The rates are reported in Table 6 together with the flowthrough experiments.

Also included in Table 6 is the $\mathrm{pH}$ of solutions corrected for temperature. These temperatures were calculated based on the $\mathrm{pHs}$ reported at $25^{\circ} \mathrm{C}$. The equivalent $\mathrm{pH}$ at temperature was calculated using the geochemical modeling code Geochemist's Workbench (Bethke, 1998) and GEMBOCHS database version V8.R6 (Johnson and Lundeen, 1997). 
Table 6. Average rates of glass dissolution based on data reported in Appendices 1-4.

\begin{tabular}{cccccc}
\hline Temp ${ }^{\circ} \mathrm{C}$ & $\begin{array}{c}\text { Time } \\
(\text { days })\end{array}$ & $\begin{array}{c}\text { Flow Rate } \\
(\mathrm{mL} / \mathrm{min})\end{array}$ & $\begin{array}{c}\mathrm{pH} \\
\text { at T }\end{array}$ & $\begin{array}{c}\mathrm{Si} \\
(\log \mathrm{mol} / \mathrm{L})\end{array}$ & $\begin{array}{c}\text { Rate } \\
\left(\log \text { mol glass } \mathrm{m}^{-2} \mathrm{sec}^{-1}\right)\end{array}$ \\
\hline 40 & - & 0.01 & 7.80 & $-3.55(0.04)$ & $-12.19(0.04)$ \\
40 & - & 0.1 & 8.19 & $-4.08(0.04)$ & $-11.55(0.06)$ \\
40 & - & 0.1 & 8.06 & $-2.77(0.01)$ & $-12.00(0.04)$ \\
40 & - & 1.0 & 8.05 & $-6.09(0.10)$ & $-11.24(0.04)$ \\
60 & - & 0.01 & 7.76 & $-3.08(0.01)$ & $-11.48(0.12)$ \\
60 & - & 0.1 & 7.89 & $-3.46(0.01)$ & $-10.89(0.03$ \\
60 & - & 0.1 & 7.89 & $-2.75(0.01)$ & $-11.45(0.07)$ \\
60 & - & 1.0 & 8.03 & $-4.35(0.02)$ & $-11.20(0.05)$ \\
80 & - & 0.01 & 7.87 & $-2.88(0.03)$ & $-11.39(0.09)$ \\
80 & - & 0.1 & 7.89 & $-3.11(0.01)$ & $-10.75(0.06)$ \\
80 & - & 0.1 & 7.85 & $-2.73(0.00)$ & $-11.55(0.06)$ \\
80 & - & 1.0 & 7.76 & $-3.57(0.04)$ & $-10.31(0.14)$ \\
160 & 0.92 & 0 & 7.60 & -2.66 & -8.99 \\
160 & 1.78 & 0 & 7.61 & -2.55 & -9.60 \\
160 & 2.91 & 0 & 7.61 & -2.48 & -9.79 \\
160 & 4.10 & 0 & 7.56 & -2.40 & -9.96 \\
160 & 4.97 & 0 & 7.69 & -2.34 & -9.75 \\
160 & 5.91 & 0 & 7.69 & -2.31 & -10.27 \\
160 & 6.86 & 0 & 7.70 & -2.29 & -10.23 \\
\hline
\end{tabular}

\subsection{Nuclear Melt Glass Dissolution}

Data from the JMK-1 melt glass dissolution experiments are listed in Appendices 5, 6, and 7. Appendix 5 summarizes the sampling chronology during the melt glass dissolution experiments and the corresponding reactor flow rates (in $\mathrm{mL} / \mathrm{day}$ ). Sample IDs that begin with 'RGL' indicate fluids that passed through both the pre-reactor and the melt glass reactor; samples designated 'PGL' passed through only the pre-reactor, and did not interact with the melt glass.

Appendix 6 contains the results of magnetic sector ICP-MS analyses of Si and U concentrations and ${ }^{238} \mathrm{U} /{ }^{235} \mathrm{U}$ ratios in the reactor solutions. The table also includes calculated values for the relative fraction of $U$ dissolved from the pre-reactor and melt glass ( $N_{\mathrm{w}}$ and $S_{\mathrm{w}}$, respectively). As anticipated, the measured ${ }^{238} \mathrm{U} /{ }^{235} \mathrm{U}$ ratios of the prereactor solutions ('PGL') are all very close to the natural ratio (137.88), and this ratio has been used in the calculations. In contrast, the solution exiting the melt glass reactor ('RGL') had measured ${ }^{238} \mathrm{U} /{ }^{235} \mathrm{U}$ ratios ranging from 97.1 to 70.0 . Despite the difference in isotopic ratios, there is generally no significant difference in the measured $U$ concentrations of the 'PGL' and 'RGL' samples at a given reaction temperature (Appendix 6). Thus, the isotope data clearly indicate that uranium from the melt glass is going into solution, while the concentration data show that the net contribution from the melt glass is small - which is consistent with near-saturated conditions. This relationship is quantified by the values for $N_{\mathrm{w}}, S_{\mathrm{w}}$, and $Q$ in Appendix 6, where $Q=N_{\mathrm{w}} / S_{\mathrm{w}}$. These 
data show that the fraction of dissolved $U$ from the melt glass comprises only 5 to $12 \%$ of the total amount of $\mathrm{U}$ in solution. The measured $\mathrm{Si}$ concentrations exhibit variations at each reaction temperature. Both $\mathrm{Si}$ and $\mathrm{U}$ show distinct increases in their average concentrations with temperature, which reflect enhanced glass dissolution rates at higher temperatures.

Appendix 7 reports the calculated glass dissolution rates for the melt glass samples. A summary of the relevant data is presented in Table 7. The dissolution rates for the nuclear melt glass were based on the $U$ isotope data. For the $60^{\circ} \mathrm{C}$ rate data, a standard deviation could not be estimated because only two data points were reported. Since $\mathrm{pH}$ was not measured, the $\mathrm{pH}$, corrected for temperature, was estimated based on the $\mathrm{pHs}$ measured for the analog glass experiments.

Table 7. Average rates of glass dissolution based on data reported in Appendix 7.

\begin{tabular}{ccccc}
\hline Temp ${ }^{\circ} \mathrm{C}$ & $\begin{array}{c}\text { Flow Rate } \\
(\mathrm{mL} / \mathrm{min})\end{array}$ & $\begin{array}{c}\mathrm{pH} \\
\text { at T }\end{array}$ & $\begin{array}{c}\mathrm{Si} \\
(\log \mathrm{mol} / \mathrm{L})\end{array}$ & $\begin{array}{c}\text { Rate } \\
\left(\log \mathrm{mol} \mathrm{glass} \mathrm{m}^{-2} \mathrm{sec}^{-1}\right)\end{array}$ \\
\hline 40 & 0.009 & 7.80 & $-3.52(0.08)$ & $-11.66(0.08)$ \\
60 & 0.009 & 7.76 & $-3.28(0.11)$ & $-11.14(?)^{*}$ \\
80 & 0.010 & 7.87 & $-2.86(0.09)$ & $-10.77(0.02)$ \\
\hline
\end{tabular}

* Standard deviation could not be calculated.

\subsection{Modeling Glass Dissolution}

The data reported in Tables 6 and 7 can be compared to the predicted glass dissolution rates based on the TST model (Equation 1). To properly evaluate these data, the saturation state of these solutions with respect to the analog and nuclear melt glass needs to be known. The saturation state $(\mathrm{Q} / \mathrm{K})$ of the solutions was based on the activity of aqueous $\mathrm{SiO}_{2}(\mathrm{aq})$ and the solubility of amorphous silica from the GEMBOCHS database (Johnson and Lundeen, 1997). We plot all the data in Figure 7 with the $1-Q / K$ term along the $\mathrm{x}$-axis and the log dissolution rate on the $\mathrm{y}$-axis.

Along with the data, we have plotted two sets of predicted glass dissolution rate functions. The first is based on the model used in recent Cheshire HST simulations (Pawloski et al., 2001) and the second is based on a TST model with adjusted parameters. In the CHESHIRE model (Pawloski et al., 2001), the $s$ and $u$ terms and the close-tosaturation term were ignored. The activation energy was set to $20 \mathrm{kcal} / \mathrm{mol}, Q$ was set by the aqueous activity of $\mathrm{SiO}_{2}(\mathrm{aq}), \mathrm{K}$ was set by the solubility of amorphous $\mathrm{SiO}_{2}$, and the rate constant and affinity terms were of the following form:

$$
k_{0} \times \prod_{i} a_{i}^{n_{i}} \approx 10^{-11.59}+10^{-8.01} \times\left(O H^{-}\right)^{0.5155}+10^{-9.51} \times\left(H^{+}\right)^{0.4566}
$$

In the modified model, the close-to-saturation term was ignored while the $\sigma$ term was set to 100 ( $v$ term not used). The activation energy was set to $12 \mathrm{kcal} / \mathrm{mol}$, the $Q$ and $K$ terms 
were treated as before, and the rate constant and affinity terms were of the following form: ${ }^{7}$

$$
k_{0} \times \prod_{i} a_{i}^{n_{i}} \approx 10^{-11.33}+10^{-8.28} \times\left(O H^{-}\right)^{0.5519}+10^{-9.24} \times\left(H^{+}\right)^{0.4825}
$$

Justification for the modified model will be given below.

\subsubsection{General Trends in Glass Dissolution Data}

The following observations can be made based on the set of collected experimental data:

- At all temperatures, the dissolution rates tend to decrease with $1-Q / K$, with approximately a 1-order-of-magnitude variation between the least saturated and most saturated sample.

- The dissolution rates based on the nuclear melt glass are consistent with the analog glass results, suggesting that the two glasses behave similarly.

- Rates increase drastically with temperature.

It should be noted that all analog flow-through data were calculated by assuming that background Mo concentrations were negligible. ${ }^{8}$ While this is a reasonable assumption in most cases, it may result in an overestimate of the glass dissolution rate in certain cases. For example, at $1-Q / K=0.38$ and at $40^{\circ} \mathrm{C}$, background Mo accounts for nearly $75 \%$ of the Mo in solution. The high background is the result of the very slow dissolution rates of the Mo-doped glass under these conditions. In general, when Mo concentrations approach $0.1 \mathrm{ppb}$, the fraction of background Mo in the effluent becomes significant. To err on the side of conservative glass dissolution rates, background subtraction was not employed in any of the glass dissolution rate calculations.

Another factor to acknowledge is that at high flow rates $(1.0 \mathrm{~mL} / \mathrm{min}$.), it cannot be assumed that flowing fluids access the entire volume of glass. It may be possible that preferential flow in the columns at these flow rates would artificially reduce the apparent glass dissolution rates. This is likely to be the case in the $60^{\circ} \mathrm{C}$ low saturation data which resulted in glass dissolution rates apparently slower than the data at higher saturation.

\footnotetext{
${ }^{7}$ The rate constant and affinity terms differ slightly from the original unclassified model of Pawloski et al. (2001) due to subtle improvements to the original data fitting. However, this effect is rather minor.

${ }^{8}$ Trace concentrations of Mo are pervasive in the laboratory, resulting in high background Mo concentrations in all solutions used in the laboratory.
} 


\subsubsection{Comparing Glass Dissolution Data to Model Predictions}

Predicted glass dissolution rates based on the TST model recently used in CHESHIRE simulations (Pawloski et al., 2001) are presented in Figure 7 (thin dashed lines). Comparison of these model predictions with experimental data suggests that the glass dissolution model used in CHESHIRE simulations was quite conservative. The most dramatic difference between predicted and experimental dissolution rates appears to occur at the higher temperatures, suggesting that the activation energy used in the CHESHIRE near-field model was high $(20 \mathrm{kcal} / \mathrm{mol})$. Yokohama and Banfield (2002) recently measured the dissolution rates of rhyolite glass from Japan at relatively low aqueous silica concentrations. Based on $50^{\circ} \mathrm{C}, 30^{\circ} \mathrm{C}$, and $15^{\circ} \mathrm{C}$ data, they estimated an activation energy of $15 \mathrm{kcal} / \mathrm{mol}$. As shown in Figure 1, this reduced activation energy would result in an order of magnitude decrease in predicted glass dissolution rates at $160^{\circ} \mathrm{C}$. While this does not reduce the predicted glass dissolution rate enough to arrive at a good model fit to the experimental data, it brings the predicted and experimental data closed together.

Because measured glass dissolution rates appear to be significantly lower than predicted rates even under relatively unsaturated conditions, the TST model parameter that would best account for the observed behavior is the stoichiometric number $\sigma$ (See Figure 3 and compare with Figure 4). Predicted glass dissolution rates based on adjusted $\sigma$ parameter and activation energy are presented in Figure 7 (thick lines). The TST model was adjusted in the following manner:

- Activation energy was reduced from $20 \mathrm{kcal} / \mathrm{mol}$ to $12 \mathrm{kcal} / \mathrm{mol}^{9}$

- The stoichiometric number was employed with a value of 100 .

While the fit is only approximate, and relatively conservative for the $160^{\circ} \mathrm{C}$ data, the model is significantly more consistent with the data than the earlier CHESHIRE glass model. Furthermore, it is interesting to note that, when using this adjusted model, the predicted dissolution rates compare well with the values reported by Yokohama and Banfield (2002) for $15^{\circ} \mathrm{C}, 30^{\circ} \mathrm{C}$, and $50^{\circ} \mathrm{C}$ glass dissolution $\left(2.1 \times 10^{-17}, 8.2 \times 10^{-17}\right.$, and $4.1 \times 10^{-16}$ versus $3.5 \times 10^{-17}, 8.7 \times 10^{-17}$, and $6.1 \times 10^{-16} \mathrm{~mol} / \mathrm{m}^{2} / \mathrm{sec}$, respectively). This provides additional evidence that the adjusted glass dissolution model can predict glass dissolution rates reasonably well.

Some additional discussion of the source of the high stoichiometry number is relevant. While this value improves the fit to the data, this stoichiometry number is too high to have a realistic physical significance. ${ }^{10}$ A $\sigma$ of 100 suggests, in fact, that our TST

\footnotetext{
${ }^{9}$ An activation energy of $12 \mathrm{kcal} / \mathrm{mol}$ was used instead of $15 \mathrm{kcal} / \mathrm{mol}$ to arrive at a better model fit.

${ }^{10}$ Bourcier et al. (1994) reported that $\sigma=10$ fit their data on dissolution of waste glasses at $100^{\circ} \mathrm{C}$.
} 
model may not be accounting for other processes that may slow glass dissolution. One likely reaction that has not been accounted for by our model is the potential for dissolution inhibition by aqueous Al. Oelkers et al. (1994) suggested that aqueous Al may be a prominent inhibitor of aluminosilicate dissolution. Published experimental data suggest an inhibition value of $[\mathrm{Al}]^{-1}$ for kaolinite and $[\mathrm{Al}]^{-0.33}$ for albite. In Figure 8 , we present the predicted glass dissolution rate at $40^{\circ} \mathrm{C}$ based on the CHESHIRE model, based on $\sigma=100$, and based on $\sigma=1$ (i.e. no exponent) and an $\mathrm{Al}$ inhibition function consistent with that observed by Oelkers et al. (1994) for albite. Clearly, the reduced dissolution rates observed in our experiments may result from the inhibitory nature of $\mathrm{Al}$ on the glass surface. ${ }^{11}$ It is also interesting to note that the inhibitory nature of $\mathrm{Al}$ (based on congruent dissolution of the glass) cannot be distinguished from the effect of the stoichiometry number, $\sigma$. Based on these results, it appears that either an $\mathrm{Al}$ inhibition model or a high stoichiometry number could be used to bring the glass dissolution model used in near-field HST simulations closer to the experimentally observed glass dissolution rates.

\footnotetext{
${ }^{11}$ Note that, if the values based on the data of kaolinite were used, the inhibition would be significantly more severe.
} 


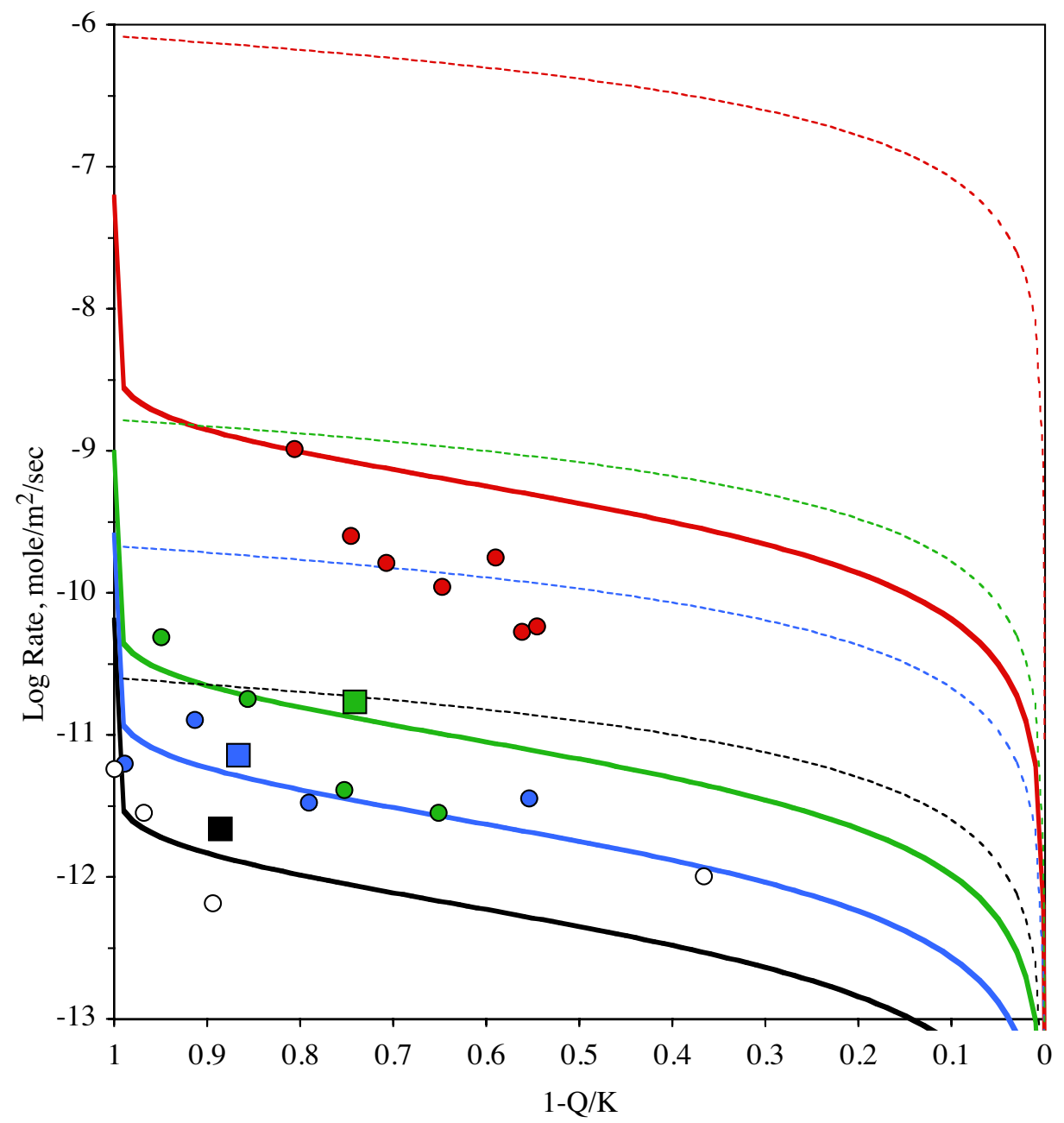

Figure 7. Comparison of predicted to measured glass dissolution rates. Predicted rates based on the glass dissolution rate equation used in Pawloski et al. (2001) (thin dashed lines), and rates based on the adjusted glass dissolution rate model (thick lines). Nuclear melt glass data (squares) and analog glass data (circles). $\mathrm{T}=4^{\circ} \mathrm{C}$ (black), $\mathrm{T}=60^{\circ} \mathrm{C}$ (blue), $\mathrm{T}=80^{\circ} \mathrm{C}$ (green), and $\mathrm{T}=160^{\circ} \mathrm{C}$ (red). 


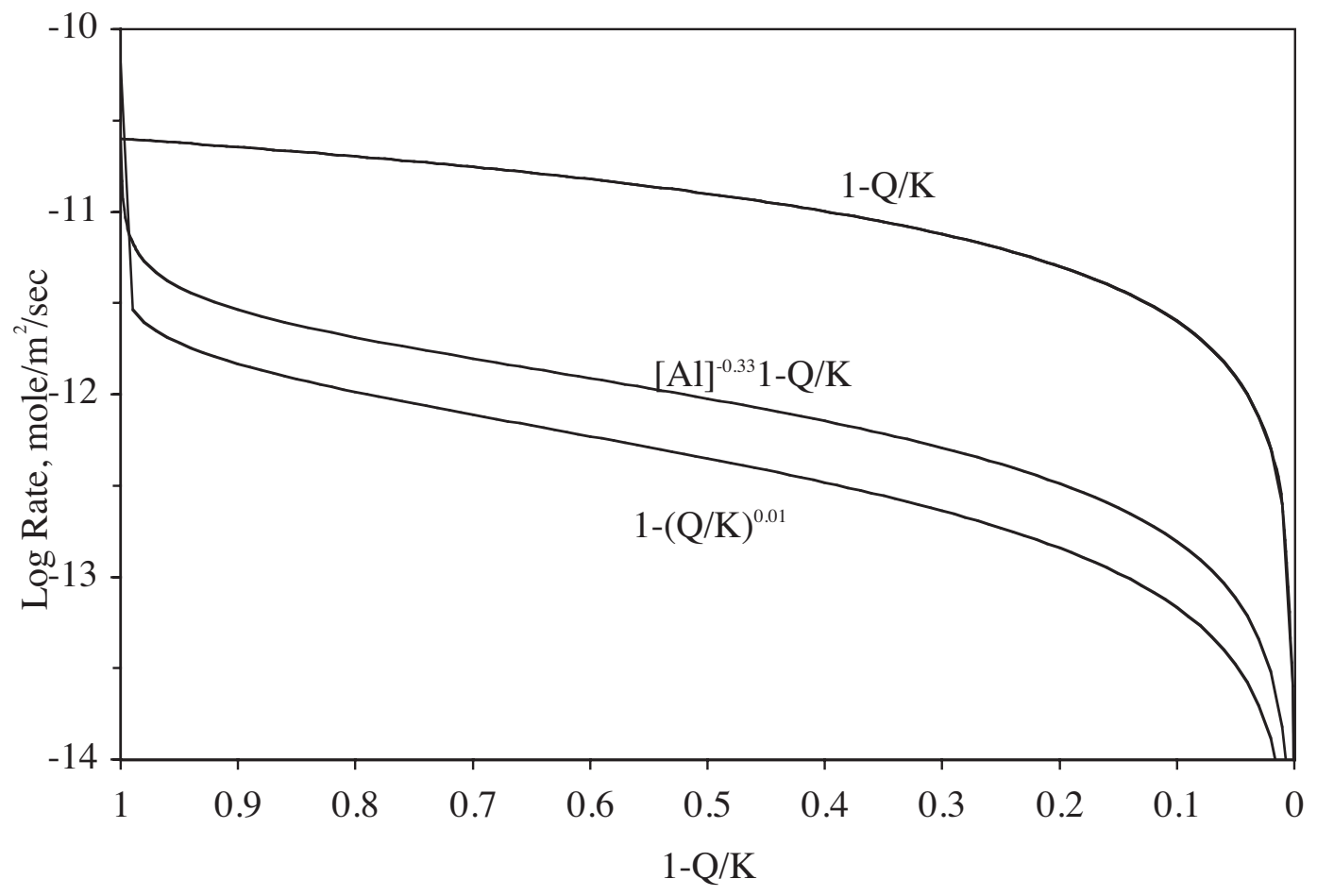

Figure 8. The effect of $\mathrm{Al}$ inhibition on glass dissolution rate as a function of saturation state at $40^{\circ} \mathrm{C}$.

\section{CONCLUSIONS AND RECOMMENDATIONS}

Based on the reported experimental data:

- Dissolution rates of analog and nuclear melt glasses are equivalent.

- It appears that glass dissolution rates in recent HST simulations (Pawloski et al., 2001; Wolfsberg et al., 2001) were too fast, particularly at high temperatures.

- In future simulations, the activation energy for glass should be reduced from $20 \mathrm{kcal} / \mathrm{mol}$ to between 15 and $12 \mathrm{kcal} / \mathrm{mol}$.

- Glass dissolution appears to slow down at even low saturation levels. The effect of solution saturation on glass dissolution can be modeled either with a high stoichiometry number $(\sigma=100)$ or by accounting for the likely inhibition of glass dissolution by aqueous $\mathrm{Al}$.

With regard to the fourth point listed above, the most appropriate method by which to account for the reduced glass dissolution rates as a function of solution saturation needs further examination. While the role of $\mathrm{Al}$ in inhibiting the dissolution of aluminosilicates has been widely observed, it is not yet clear how glass dissolution and secondary mineral precipitation will be affected in the complex and heterogeneous glass zone of a nuclear test cavity. 


\section{ACKNOWLEDGEMENTS}

Funding for this investigation was provided by the Environment Restoration Division's Underground Test Area Project at the U.S. Department of Energy, National Nuclear Security Administration, Nevada Site Office. This work was performed under the auspices of the U.S. Department of Energy by Lawrence Livermore National Laboratory under contract number W-7405-Eng-48.

\section{REFERENCES}

Bethke, C. M. (1998) The Geochemist's Workbench: Release 3.0. University of Illinois. Bourcier, W.L., Carroll, S.A., and Phillips, B.L. (1994) Constraints on the affinity term for modeling long-term glass dissolution rates. Materials Research Society Symposium Proceedings, 333: 507-512.

Bourcier, W.L., Roberts, S.K., Newton, L., Sawvel, A., Bruton, C. (2000) Part 2. Determination of reactive surface areas from flow-through test of natural analog glass samples In Determination of Reactive Surface Area of Melt Glass, Bourcier, W. Roberts, S., Smith, D.K., Hulsey, S., Newton, L., Sawverl, A., Bruton, C., Papelis, C., Um, W., Russel, C.E., and Chapman, J., UCRL-ID145181, Lawrence Livermore National Laboratory, Livermore, California.

Brunauer, S., Emmet, P.H., and Teller, E. (1938) Adsorption of gases in multimolecular layers. Journal American Chemican Society, 60: 309-318.

Faure, G. (1986) Principles of Isotope Geology, Second Edition. Wiley, New York, $589 \mathrm{p}$.

Johnson J. W. and Lundeen S. R. (1997) GEMBOCHS thermodynamic datafiles for use with the EQ3/6 modeling package. Internal Report, Lawrence Livermore National Laboratory, Livermore, California.

Jorgensen, S.S. (1968) Solubility and dissolution kinetics of precipitated amorphous silica in $1 \mathrm{M} \mathrm{NaClO}_{4}$ at $25^{\circ} \mathrm{C}$. Acta Chemica Scandinavica, 22, 335-341.

Langmuir, D. (1978) Uranium solution-mineral equilibria at low temperatures with applications to sedimentary ore deposits. Geochimica et Cosmochimica Acta, 42: 547-569.

Mazer, J.J. (1987) Kinetics of glass dissolution as a function of temperature, glass composition, and solution pH's. Ph.D. thesis, Northwestern University.

Moore, L.J., Moody, J.R., Barnes, I.L., Gramich, J.W., Murphy, T.J., Paulsen, P.J., and Shields, W.R. (1973) Trace determination of rubidium and strontium in silicate glass standard reference materials. Analytical Chemistry, 45: 2384-2387.

Oelkers, E.H., Schott, J., and Devidal, J-L. (1994) The effect of aluminum, pH, and chemical affinity on the rates of aluminum dissolution reactions. Geochimica et Cosmochimica Acta, 58: 2011-2024.

Papelis, C., Um, W., Russell, C.E., and Chapman, J.B. (2000) Measuring the specific surface area of natural and man-made glasses. Effect of formation process, morphology, and particle size. In Determination of Reactive Surface Area of Melt Glass, Bourcier, W. Roberts, S., Smith, D.K., Hulsey, S., Newton, L., Sawverl, A., Bruton, C., Papelis, C., Um, W., Russel, C.E., and Chapman, J., UCRL-ID145181, Lawrence Livermore National Laboratory, Livermore, California. 
Pawloski G. A., Tompson A. F. B., Bruton C. J., and Zavarin M., Eds. (2000) Evaluation of the Hydrologic Source Term from Underground Nuclear Tests in Frenchman Flat and the Nevada Test Site (U). Contributors: W.L. Bourcier, C.J. Bruton, S.F. Carle, B.K. Esser, A.B. Kersting, R.M. Maxwell, G.A. Pawloski, J.A. Rard, D.E. Shumaker, D.K. Smith, A.F.B. Tompson, and M. Zavarin. UCRL-ID-138007, Lawrence Livermore National Laboratory, Livermore, California.

Pawloski G. A., Tompson A. F. B., and Carle S. F. (2001) Evaluation of the Hydrologic Source Term from Underground Nuclear Tests on Pahute Mesa at the Nevada Test Site: The CheshiRE Test, Bourcier, W.L., Bruton, C.J., Carle, S.F., Daniels, J.I., Maxwell, R.M., Pawloski, G.A., Shumaker, D.S., Smith, D.K., Tompson, A.F.B., and Zavarin, M., Contributors. UCRL-ID-147023, Lawrence Livermore National Laboratory, Livermore, California.

Tompson A. F. B., Bruton C. J., and Pawloski G. A. (1999) Evaluation of the hydrologic source term from the underground nuclear tests in Frenchman Flat and the Nevada Test Site: The CAMBRIC test. UCRL-ID-132300, Lawrence Livermore National Laboratory, Livermore, California.

Wolfsberg, A. Glascoe, L., Lu, G., Olson, A., Lichtner, P. McGraw, M., Cherry, T., Roemer, G. 2002. Tybo/Benham: Model Analysis of Groundwater Flow and Radionuclide Migration from Undergrounds Nuclear Tests in Southwestern Pahute Mesa, Nevada, LA-13977, Los Alamos National Laboratory, Los Alamos, New Mexico.

Yokoyama, T., and Banfield, J.F. (2002) Direct determinations of the rates of rhyolite dissolution and clay formation over 52,000 years and comparison with laboratory measurements. Geochim. Cosmochim. Acta, 66, No.15, 2665-2681.

Zavarin, M., Roberts, S.K., Viani, B.E., Pawloski, G.A., and Rose, T.P. (2004) Nuclear Melt Glass Dissolution and Secondary Mineral Precipitation at 40 to $200^{\circ} \mathrm{C}$, UCRL-TR-204870, Lawrence Livermore National Laboratory, Livermore, California. 
APPENDIX 1. ANALYTICAL DATA FROM THE MO-DOPED GLASS STATIC DISSOLUTION EXPERIMENT AT 40 ${ }^{\circ} \mathrm{C}$

\begin{tabular}{|c|c|c|c|c|c|c|c|c|c|c|c|}
\hline \multicolumn{5}{|c|}{$\begin{array}{l}\text { Mo-doped glass SPFT Experiment } \# 5 \\
\text { Mass of Mo-doped glass }=1.8057 \text { grams }\end{array}$} & \multicolumn{6}{|c|}{$\begin{array}{l}\text { Buffer solution of } 0.001 \text { Molar } \mathrm{NaHCO}_{3} \\
\text { Mass of pre-reactor LCO glass }=68.59 \text { grams }\end{array}$} & \multirow[b]{2}{*}{$\begin{array}{r}\text { Si } \\
\text { ppm }\end{array}$} \\
\hline Sample \# & $\begin{array}{c}\text { Collection } \\
\text { Time } \\
\text { hrs }\end{array}$ & $\begin{array}{c}\text { Solution } \\
\text { mass } \\
\text { g }\end{array}$ & $\mathbf{p H}$ & $\begin{array}{l}\text { Flow-Rate } \\
\text { mL/min }\end{array}$ & $\begin{array}{l}\text { Mo } \\
\text { ppb }\end{array}$ & $\begin{array}{c}\text { Al } \\
\text { ppm }\end{array}$ & $\begin{array}{c}\text { Ca } \\
\text { ppm }\end{array}$ & $\begin{array}{c}\mathrm{K} \\
\mathbf{p p m} *\end{array}$ & $\begin{array}{c}\text { Mg } \\
\text { ppm }\end{array}$ & $\begin{array}{c}\mathrm{Na} \\
\mathbf{p p m}\end{array}$ & \\
\hline \multicolumn{12}{|c|}{$0.01 \mathrm{~mL} / \mathrm{min}$} \\
\hline Mo\#5-1 & 17.20 & 10.127 & 7.91 & 0.010 & 1.24 & 0.97 & 0.03 & n.d. & 0.02 & 24 & 9.0 \\
\hline Mo\#5-2 & 16.90 & 9.714 & 7.76 & 0.010 & 1.03 & 0.80 & 1.10 & 0.17 & 0.02 & 24 & 7.8 \\
\hline Mo\#5-3 & 16.85 & 9.903 & 8.24 & 0.010 & 1.14 & 0.87 & 1.20 & 0.38 & 0.02 & 24 & 7.5 \\
\hline Mo\#5-4 & 17.67 & 10.631 & 7.67 & 0.010 & 1.26 & 0.88 & 1.20 & 2.2 & 0.02 & 24 & 7.5 \\
\hline PR\#5-1 & 15.73 & 9.320 & 8.43 & 0.010 & 0.49 & 0.89 & 1.10 & n.d. & 0.02 & 24 & 7.3 \\
\hline \multicolumn{12}{|l|}{$0.1 \mathrm{~mL} / \mathrm{min}$} \\
\hline Mo\#5-5 & 2.30 & 13.420 & 8.50 & 0.097 & 0.47 & 0.57 & 1.20 & 0.71 & 0.03 & 24 & 2.5 \\
\hline Mo\#5-6 & 1.67 & 9.756 & 8.10 & 0.098 & 0.49 & 0.45 & 1.20 & n.d. & 0.03 & 23 & 2.6 \\
\hline Mo\#5-7 & 1.67 & 9.885 & 8.35 & 0.099 & 0.43 & 0.38 & 2.10 & 0.96 & 0.03 & 23 & 2.2 \\
\hline Мo\#5-8 & 2.20 & 13.061 & 8.22 & 0.099 & 0.53 & 0.32 & 1.20 & n.d. & 0.03 & 24 & 2.1 \\
\hline Mo\#5-9 & 2.05 & 12.206 & 8.45 & 0.099 & 0.62 & 0.45 & 1.60 & n.d. & 0.03 & 23 & 2.4 \\
\hline PR\#5-2 & 1.87 & 11.303 & 7.94 & 0.101 & 0.13 & 0.38 & 1.10 & 0.22 & 0.02 & 23 & 1.7 \\
\hline \multicolumn{12}{|c|}{ Switched solution to $0.001 \mathrm{NaHCO}_{3}, 100 \mathrm{ppm} \mathrm{SiO}_{2}$} \\
\hline Mo\#5-10 & 2.22 & 12.903 & 8.37 & 0.097 & 0.19 & 0.21 & 1.30 & n.d. & 0.05 & 96 & 47 \\
\hline Mo\#5-11 & 2.40 & 13.887 & 8.08 & 0.096 & 0.19 & 0.20 & 1.10 & n.d. & 0.04 & 96 & 47 \\
\hline Mo\#5-12 & 2.02 & 11.627 & 8.15 & 0.096 & 0.18 & 0.02 & 1.20 & n.d. & 0.03 & 96 & 48 \\
\hline Mo\#5-13 & 1.65 & 10.038 & 8.17 & 0.101 & 0.16 & 0.10 & 1.20 & n.d. & 0.02 & 97 & 48 \\
\hline Mo\#5-14 & 2.32 & 13.409 & 8.14 & 0.096 & 0.16 & 0.22 & 1.10 & 0.97 & 0.02 & 97 & 48 \\
\hline PR\#5-3 & 1.03 & 6.164 & 8.00 & 0.099 & 0.14 & 0.15 & 2.50 & n.d. & 0.03 & 98 & 48 \\
\hline \multirow{2}{*}{\multicolumn{12}{|c|}{$\begin{array}{l}1.0 \mathrm{~mL} / \mathrm{min} \\
\text { Switched solution to } 0.001 \mathrm{NaHCO}_{3}\end{array}$}} \\
\hline & & & & & & & & & & & \\
\hline Mo\#5-15 & 0.20 & 11.799 & 8.21 & 0.983 & 0.35 & 0.15 & 1.90 & 0.26 & 0.02 & 23 & 0.7 \\
\hline Mo\#5-16 & 0.22 & 12.761 & 8.11 & 0.982 & 0.10 & 0.08 & 0.95 & n.d. & 0.01 & 23 & 0.02 \\
\hline Mo\#5-17 & 0.24 & 14.551 & 8.11 & 1.004 & 0.11 & 0.10 & 1.20 & n.d. & 0.01 & 23 & 0.02 \\
\hline Mo\#5-18 & 0.20 & 11.792 & 8.25 & 0.983 & 0.09 & 0.15 & 0.87 & n.d. & 0.01 & 23 & 0.03 \\
\hline PR\#5-4 & 0.22 & 12.930 & 8.15 & 0.995 & 0.08 & 0.13 & 1.10 & 1.6 & 0.02 & 23 & 0.05 \\
\hline \multicolumn{5}{|c|}{$1 \mathrm{M} \mathrm{NaHCO}_{3}-1$} & 0.05 & 0.11 & 1.00 & n.d. & 0.01 & 23 & n.d. \\
\hline \multicolumn{5}{|c|}{$1 \mathrm{M} \mathrm{NaHCO}_{3}-2$} & 0.05 & 0.04 & 0.93 & n.d. & 0.01 & 23 & n.d. \\
\hline \multicolumn{5}{|c|}{100 ppm $\mathrm{SiO}_{2}-1$} & & & & & & & 48 \\
\hline \multicolumn{5}{|c|}{101 ppm $\mathrm{SiO}_{2}-2$} & & & & & & & 47 \\
\hline
\end{tabular}

n.d. $=$ below detection limit 
APPENDIX 2. ANALYTICAL DATA FROM THE MO-DOPED GLASS STATIC DISSOLUTION EXPERIMENT AT 60

Mo-doped glass SPFT Experiment \#3 Mass of Mo-doped glass $=1.8057$ grams

\begin{tabular}{|c|c|c|c|c|c|c|c|c|c|c|c|c|}
\hline & Sample \# & $\begin{array}{c}\text { Collection Time } \\
\text { hrs }\end{array}$ & $\begin{array}{c}\text { Solution } \\
\text { mass } \\
\mathrm{g} \\
\end{array}$ & pH & $\begin{array}{c}\text { Flow-Rate } \\
\mathrm{mL} / \mathrm{min}\end{array}$ & $\begin{array}{l}\text { Mo } \\
\text { ppb }\end{array}$ & $\begin{array}{c}\text { Al } \\
\text { ppm }\end{array}$ & $\begin{array}{c}\mathrm{Ca} \\
\mathrm{ppm}\end{array}$ & $\begin{array}{c}\mathrm{K} \\
\mathbf{p p m} *\end{array}$ & $\begin{array}{c}\text { Mg } \\
\text { ppm }\end{array}$ & $\begin{array}{c}\mathrm{Na} \\
\mathbf{p p m}\end{array}$ & $\begin{array}{c}\text { Si } \\
\text { ppm }\end{array}$ \\
\hline & \multicolumn{12}{|l|}{$0.01 \mathrm{~mL} / \mathrm{min}$} \\
\hline & Mo\#3-1 & 10.48 & 6.183 & 8.06 & 0.010 & 8.49 & 3.755 & 0.591 & 1.694 & 0.007 & 31.90 & 24.37 \\
\hline & Mo\#3-2 & 14.72 & 9.347 & 7.93 & 0.011 & 6.33 & 3.716 & 0.682 & 1.322 & 0.007 & 31.24 & 23.22 \\
\hline & Mo\#3-3 & 13.48 & 8.152 & 7.85 & 0.010 & 5.32 & 3.997 & 0.584 & 1.094 & 0.006 & 30.94 & 23.20 \\
\hline & Mo\#3-4 & 22.72 & 13.865 & 7.91 & 0.010 & 4.42 & 4.051 & 0.569 & 0.988 & 0.006 & 30.91 & 22.96 \\
\hline & PR\#3-2 & 16.72 & n.m. & $n . m$. & $n . m$. & 0.20 & 3.914 & 0.682 & 0.931 & 0.009 & 30.92 & 21.85 \\
\hline & \multicolumn{12}{|l|}{$0.1 \mathrm{~mL} / \mathrm{min}$} \\
\hline & Mo\#3-5 & 2.02 & 11.738 & 8.11 & 0.097 & 2.05 & 1.817 & 1.333 & 0.635 & 0.029 & 25.22 & 9.30 \\
\hline & Mo\#3-6 & 2.17 & 12.688 & 8.17 & 0.098 & 2.44 & 1.803 & 0.657 & 2.453 & 0.008 & 26.01 & 9.73 \\
\hline & Mo\#3-7 & 2.45 & 14.195 & 8.07 & 0.097 & 2.23 & 1.836 & 0.804 & 2.336 & 0.011 & 25.86 & 9.77 \\
\hline & Mo\#3-8 & 2.17 & 12.803 & 8.16 & 0.098 & 2.39 & 1.824 & 0.837 & 2.193 & 0.047 & 24.89 & 9.78 \\
\hline & Mo\#3-9 & 1.33 & 7.819 & 8.10 & 0.098 & 2.28 & 1.840 & 1.017 & 1.739 & 0.053 & 24.38 & 9.86 \\
\hline 0 & PR\#3-3 & 0.52 & n.m. & n.m. & n.m. & 0.31 & 1.982 & 0.692 & 1.229 & 0.038 & 28.46 & 11.13 \\
\hline & \multicolumn{12}{|c|}{ Switched solution to $0.001 \mathrm{NaHCO}_{3}, 100 \mathrm{ppm} \mathrm{SiO}$} \\
\hline & Mo\#3-9a & 1.85 & 10.415 & 8.05 & 0.094 & 0.82 & 0.321 & 0.961 & 2.329 & 0.074 & 84.52 & 49.24 \\
\hline & Mo\#3-10 & 2.22 & 12.565 & 8.03 & 0.094 & 0.65 & 0.296 & 1.098 & 1.848 & 0.058 & 84.68 & 50.88 \\
\hline & Mo\#3-11 & 2.02 & 11.435 & 8.22 & 0.095 & 0.60 & 0.221 & 0.883 & 1.023 & 0.033 & 84.86 & 49.54 \\
\hline & Mo\#3-12 & 2.58 & 15.090 & n.m. & 0.097 & 0.56 & 0.254 & 0.891 & 1.208 & 0.026 & 86.14 & 49.50 \\
\hline & Mo\#3-13 & 1.77 & 10.225 & 8.18 & 0.096 & 0.57 & 0.185 & 0.837 & 1.007 & 0.020 & 87.63 & 50.52 \\
\hline & PR\#3-4 & 0.98 & n.m. & $n . m$. & $n . m$. & 0.24 & 0.201 & 0.798 & 0.313 & 0.021 & 86.90 & 51.00 \\
\hline & \multicolumn{12}{|l|}{$1.0 \mathrm{~mL} / \mathrm{min}$} \\
\hline & Mo\#3-14 & 0.18 & 10.963 & 8.28 & 0.997 & 0.10 & 0.322 & 0.611 & -0.610 & 0.003 & 19.64 & 1.33 \\
\hline & \multicolumn{12}{|c|}{ Switched solution to $0.001 \mathrm{NaHCO}_{3}$} \\
\hline & Mo\#3-15 & n.m. & n.m. & 8.32 & n.m. & 0.11 & 0.236 & 0.815 & -0.426 & 0.005 & 19.76 & 1.26 \\
\hline & Mo\#3-16 & n.m. & n.m. & 8.32 & n.m. & 0.10 & 0.236 & 0.796 & -0.660 & 0.005 & 19.81 & 1.26 \\
\hline & Mo\#3-17 & n.m. & n.m. & 8.40 & n.m. & 0.13 & 0.257 & 1.044 & -0.550 & 0.008 & 19.17 & 1.17 \\
\hline & PR\#3-5 & n.m. & n.m. & n.m. & n.m. & 0.08 & 0.408 & 0.811 & -0.489 & 0.010 & 20.66 & 2.90 \\
\hline & $1 \mathrm{M} \mathrm{NaHCO}_{3}-1$ & & & & & 0.07 & 0.020 & 0.589 & -0.451 & 0.009 & 23.41 & 0.22 \\
\hline & 100 ppm $\mathrm{SiO}_{2}$ & & & & & 0.03 & 0.000 & 0.749 & -0.545 & 0.005 & 82.97 & 48.69 \\
\hline
\end{tabular}

$n . m .=$ not measured

* Potassium analyses suspect due to detection limits

Buffer solution of 0.001 Molar $\mathrm{NaHCO}_{3}$

Mass of pre-reactor LCO glass $=68.59$ gram 
APPENDIX 3. ANALYTICAL DATA FROM THE MO-DOPED GLASS STATIC DISSOLUTION EXPERIMENT AT 80C

Mo-doped glass SPFT Experiment \#4

Buffer solution of 0.001 Molar $\mathrm{NaHCO}_{3}$

Mass of Mo-doped glass $=1.8057$ grams

Mass of pre-reactor LCO glass $=\mathbf{6 8 . 5 9}$ grams

\begin{tabular}{|c|c|c|c|c|c|c|c|c|c|c|c|}
\hline Sample \# & $\begin{array}{c}\text { Collection Time } \\
\text { hrs }\end{array}$ & $\begin{array}{c}\text { Solution } \\
\text { mass } \\
\mathrm{g} \\
\end{array}$ & $\mathbf{p H}$ & $\begin{array}{l}\text { Flow-Rate } \\
\mathrm{mL} / \mathrm{min}\end{array}$ & $\begin{array}{l}\text { Mo } \\
\text { ppb }\end{array}$ & $\begin{array}{c}\text { Al } \\
\text { ppm }\end{array}$ & $\begin{array}{c}\mathrm{Ca} \\
\text { ppm }\end{array}$ & $\begin{array}{c}\mathrm{K} \\
\mathbf{p p m} *\end{array}$ & $\begin{array}{l}\text { Mg } \\
\text { ppm }\end{array}$ & $\begin{array}{c}\mathrm{Na} \\
\mathrm{ppm}\end{array}$ & $\begin{array}{c}\text { Si } \\
\text { ppm }\end{array}$ \\
\hline \multicolumn{12}{|l|}{$0.01 \mathrm{~mL} / \mathrm{min}$} \\
\hline Mo\#4-1 & 15.32 & 9.812 & 8.46 & 0.011 & 7.97 & 6.75 & 0.93 & 1.06 & 0.01 & 34.71 & 38.01 \\
\hline Mo\#4-2 & 16.48 & 10.287 & 8.23 & 0.010 & 8.81 & 6.66 & 0.73 & 1.11 & 0.01 & 35.87 & 37.85 \\
\hline Mo\#4-3 & 14.27 & 8.346 & 8.27 & 0.010 & - & 7.47 & 0.83 & 1.05 & 0.01 & 41.13 & 41.12 \\
\hline Mo\#4-4 & 16.12 & 9.488 & 8.38 & 0.010 & 5.90 & 7.55 & 0.83 & 1.09 & 0.02 & 38.54 & 40.57 \\
\hline Mo\#4-5 & 17.37 & 11.777 & 8.18 & 0.011 & 5.73 & 6.20 & 0.79 & 0.98 & 0.01 & 33.20 & 34.47 \\
\hline Mo\#4-6 & 16.73 & 10.407 & 8.25 & 0.010 & 8.66 & 6.63 & 0.83 & 1.14 & 0.01 & 33.65 & 36.48 \\
\hline PR\#4-2 & 19.25 & 12.040 & 8.70 & 0.010 & 0.89 & 6.83 & 0.74 & 2.12 & 0.01 & 34.05 & 37.39 \\
\hline \multicolumn{12}{|l|}{$0.1 \mathrm{~mL} / \mathrm{min}$} \\
\hline Mo\#4-8 & 1.78 & 11.372 & 8.33 & 0.106 & 3.51 & 3.93 & 0.76 & 1.05 & 0.01 & 27.35 & 21.18 \\
\hline Mo\#4-9 & 1.75 & 10.745 & 8.30 & 0.102 & 3.64 & 4.19 & 1.03 & 1.01 & 0.06 & 27.17 & 21.69 \\
\hline Мo\#4-10 & 1.63 & 10.056 & 8.40 & 0.103 & 2.99 & 4.08 & 0.92 & 1.03 & 0.09 & 26.74 & 21.98 \\
\hline Mo\#4-11 & 1.60 & 9.645 & 8.34 & 0.100 & 2.72 & 4.05 & 0.91 & 1.20 & 0.09 & 26.42 & 21.82 \\
\hline PR\#4-3 & 1.57 & 9.267 & 8.29 & 0.099 & 0.41 & 4.01 & 0.92 & 2.33 & 0.09 & 26.47 & 21.49 \\
\hline \multicolumn{12}{|c|}{ Switched solution to $0.001 \mathrm{NaHCO}_{3}, 100 \mathrm{ppm} \mathrm{SiO}_{2}$} \\
\hline Mo\#4-12 & 1.82 & 9.582 & 8.36 & 0.088 & 0.62 & 1.07 & 1.04 & 3.11 & 0.08 & 101.64 & 53.27 \\
\hline Мo\#4-13 & 1.68 & 10.206 & 8.33 & 0.101 & 0.45 & 0.96 & 0.95 & 2.64 & 0.06 & 99.35 & 52.30 \\
\hline Mo\#4-14 & 1.73 & 10.830 & 8.23 & 0.104 & 0.48 & 0.95 & 0.88 & 2.67 & 0.05 & 101.30 & 52.50 \\
\hline Mo\#4-15 & 1.62 & 10.301 & 8.19 & 0.106 & 0.52 & 0.80 & 1.18 & 2.70 & 0.05 & 101.07 & 52.39 \\
\hline Mo\#4-16 & 1.62 & 9.990 & 8.19 & 0.103 & 0.47 & 0.82 & 1.25 & 2.62 & 0.05 & 101.30 & 52.83 \\
\hline PR\#4-4 & 1.80 & 10.403 & 8.24 & 0.096 & 0.09 & 0.93 & 0.93 & 2.93 & 0.05 & 100.12 & 52.37 \\
\hline \multicolumn{12}{|c|}{ Switched solution to $0.001 \mathrm{NaHCO}_{3}$} \\
\hline \multicolumn{12}{|l|}{$1.0 \mathrm{~mL} / \mathrm{min}$} \\
\hline Mo\#4-17 & 0.20 & 12.330 & 8.16 & 1.028 & 0.57 & 1.54 & 0.60 & 0.67 & 0.01 & 24.96 & 6.75 \\
\hline Mo\#4-18 & 0.18 & 11.361 & 8.03 & 1.033 & 0.67 & 1.58 & 0.97 & 0.79 & 0.01 & 25.50 & 7.20 \\
\hline Mo\#4-19 & 0.20 & 11.258 & 8.06 & 0.938 & 1.00 & 1.50 & 0.95 & 0.86 & 0.01 & 25.43 & 8.10 \\
\hline Mo\#4-20 & 0.20 & 11.567 & 8.03 & 0.964 & 1.12 & 1.60 & 0.88 & 0.91 & 0.01 & 25.58 & 7.96 \\
\hline Мo\#4-21 & 0.18 & 11.490 & 8.01 & 1.045 & 1.16 & 1.53 & 0.86 & 0.76 & 0.01 & 25.02 & 8.09 \\
\hline PR\#4-5 & 0.18 & 11.171 & 8.00 & 1.016 & 0.16 & 1.65 & 0.85 & 1.01 & 0.01 & 24.41 & 8.38 \\
\hline $1 \mathrm{M} \mathrm{NaHCO}_{3}-$ & & & & & 0.00 & - & - & - & - & - & - \\
\hline $1 \mathrm{M} \mathrm{NaHCO}_{3}-$ & & & & & 0.00 & - & - & - & - & - & - \\
\hline $100 \mathrm{ppm} \mathrm{SiO}_{2}$ & & & & & 0.03 & - & - & - & - & - & - \\
\hline
\end{tabular}

* Potassium analyses suspect due to detection limits 
APPENDIX 4. ANALYTICAL DATA FROM THE MO-DOPED GLASS STATIC DISSOLUTION EXPERIMENT AT 160 ${ }^{\circ} \mathrm{C}$

Mo-doped glass static dissolution Experiment \#1

Mass of Mo-doped glass $=9.6498$ grams

Volume of 0.001 Molar $\mathrm{NaHCO}_{3}$ buffer solution $=100 \mathrm{~mL}$

Start date $\quad 9 / 4 / 023: 30 \mathrm{PM}$

\begin{tabular}{|c|c|c|c|c|c|c|c|c|c|c|c|}
\hline Sample \# & Sample date & $\begin{array}{c}\text { Elapsed time } \\
\text { days }\end{array}$ & pH & Psi & $\begin{array}{l}\text { Mo } \\
\text { ppb }\end{array}$ & $\begin{array}{c}\text { Al } \\
\text { ppm }\end{array}$ & $\begin{array}{c}\mathrm{Ca} \\
\mathbf{p p m}\end{array}$ & $\begin{array}{c}\mathrm{K} \\
\mathbf{p p m}\end{array}$ & $\begin{array}{c}\text { Mg } \\
\text { ppm }\end{array}$ & $\begin{array}{c}\mathrm{Na} \\
\mathrm{ppm}\end{array}$ & $\begin{array}{c}\mathbf{S i} \\
\mathbf{p p m}\end{array}$ \\
\hline & & 0.00 & 8.03 & & & & & & & & \\
\hline PB1-1 & 9/5/02 1:30 PM & 0.92 & 8.07 & 86 & 1338 & 9.5 & 2.4 & 3.1 & 0.22 & 39 & 61 \\
\hline PB1-2 & 9/6/02 10:19 AM & 1.78 & 8.08 & 82 & 1684 & 12.7 & 1.4 & 5.9 & 0.15 & 42 & 80 \\
\hline PB1-3 & 9/7/02 1:15 PM & 2.91 & 8.17 & 79 & 2008 & 15.4 & 1.2 & 5.2 & 0.12 & 45 & 92 \\
\hline PB1-4 & 9/8/02 5:51 PM & 4.10 & 7.74 & 79 & 2274 & 18.8 & 1.2 & 4.0 & 0.09 & 47 & 111 \\
\hline PB1-5 & 9/9/02 2:43 PM & 4.97 & 8.80 & 78 & 2639 & 21.4 & 1.2 & 4.4 & 0.07 & 52 & 129 \\
\hline PB1-6 & 9/10/02 1:25 PM & 5.91 & 8.80 & 76 & 2782 & 22.7 & 1.1 & 5.0 & 0.06 & 55 & 138 \\
\hline PB1-7 & 9/11/02 12:15 PM & 6.86 & 8.86 & 75 & 2979 & 23.4 & 1.3 & 4.8 & 0.06 & 56 & 143 \\
\hline PB $1-8$ & 9/12/02 12:19 PM & 7.87 & 7.09 & 72 & 2013 & 14.2 & 2.0 & 3.5 & 0.13 & 40 & 94 \\
\hline PB1-9 & 9/13/02 8:55 AM & 8.73 & 7.04 & 70 & 1033 & 7.2 & 1.6 & 2.3 & 0.10 & 25 & 54 \\
\hline
\end{tabular}


APPENDIX 5. ANALYTICAL DATA FROM THE JMK-1 MELT GLASS SPFT EXPERIMENT AT $4^{\circ}, 6^{\circ}$, AND $^{\circ} 0^{\circ} \mathrm{C}$

$\begin{array}{ll}\text { Melt glass from NTS JMK-1: } & \text { sample mass } 1.0801 \mathrm{~g}, 25-53 \mathrm{~mm} \\ \text { Preshot glass: } & \text { sample mass } 14.962 \mathrm{~g}, 25-74 \mathrm{~mm}\end{array}$

Experiment start date: 6/5/02 11:00 AM

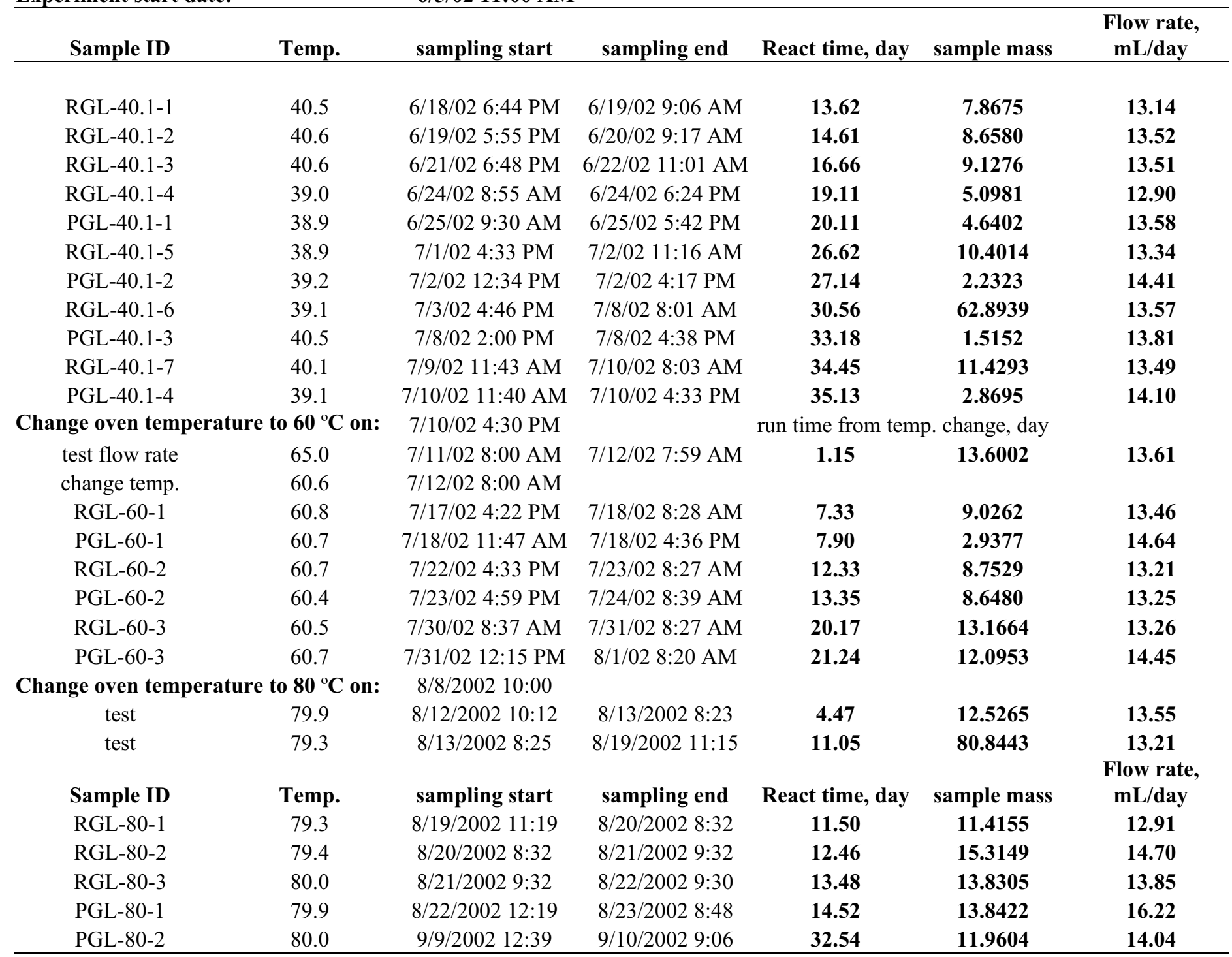


APPENDIX 6. MAGNETIC SECTOR ICP-MS ANALYSES OF SI AND U CONCENTRATIONS AND ${ }^{238} \mathrm{U}^{235} \mathrm{U}^{2 \mathrm{RATIOS}}$ IN JMK-1 REACTOR SOLUTIONS

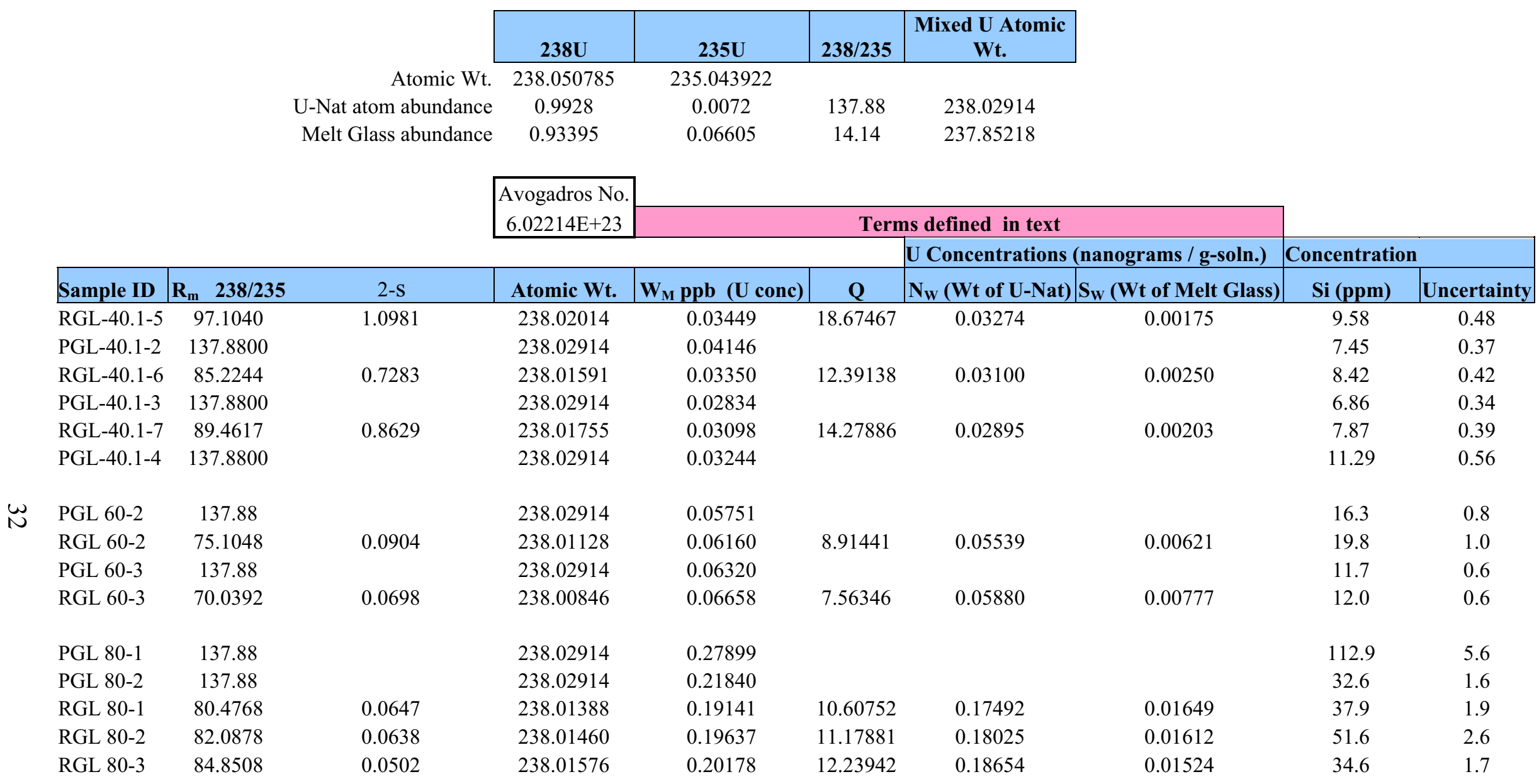




\section{APPENDIX 7. CALCULATED GLASS DISSOLUTION FOR THE PM-X PRE-REACTOR AND JMK-1 MELT GLASS SAMPLES}

Sample Properties

\begin{tabular}{|c|c|c|c|c|c|c|c|}
\hline & \multicolumn{2}{|c|}{ Pre-reactor Glass sample } & \multirow[b]{2}{*}{$\mathrm{m}^{2} / \mathrm{g}$} & & \multicolumn{2}{|c|}{ Nuclear Melt Glass sample } & \multirow[b]{2}{*}{$\mathrm{m}^{2} / \mathrm{g}$} \\
\hline & $\begin{array}{l}\text { Starting S.A. } \\
(\mathrm{BET})\end{array}$ & 0.2329 & & & $\begin{array}{r}\text { Starting S.A. } \\
\text { (BET) }\end{array}$ & 0.2969 & \\
\hline & $\begin{array}{l}\text { Glass Density } \\
\text { (est.) }\end{array}$ & 2.6 & $\mathrm{~g} / \mathrm{cm}^{3}$ & & $\begin{array}{r}\text { Glass Density } \\
\text { (est.) }\end{array}$ & 2.6 & $\mathrm{~g} / \mathrm{cm}^{3}$ \\
\hline & WtFrac Oxide & Element & $\begin{array}{l}\text { WtFrac } \\
\text { Element }\end{array}$ & & WtFrac Oxide & Element & $\begin{array}{l}\text { WtFrac } \\
\text { Element }\end{array}$ \\
\hline $\mathrm{SiO} 2$ & 0.7763 & $\mathrm{Si}$ & 0.3629 & $\mathrm{SiO} 2$ & 0.7725 & $\mathrm{Si}$ & 0.3611 \\
\hline UO3 & 0.27 & $\mathrm{U}$ & 4.448E-06 & UO3 & 0.27 & $\mathrm{U}$ & 4.637E-06 \\
\hline
\end{tabular}

Pre-Reactor Cell - Si and U Dissolution Rates (U data from $W_{m}$ values in Appendix 6)

\begin{tabular}{|c|c|c|c|c|c|c|c|c|c|c|}
\hline & $\begin{array}{l}\text { Mass of Pre- } \\
\text { Reactor Glass }\end{array}$ & $\begin{array}{l}\text { Flow } \\
\text { Rate }\end{array}$ & $\begin{array}{l}\text { Run time from } \\
\text { day } 1\end{array}$ & $\begin{array}{c}\text { Particle } \\
\text { Diameter }\end{array}$ & \multirow{2}{*}{$\begin{array}{c}\text { Surf. } \\
\text { Area } \\
\text { (sq. m) }\end{array}$} & \multicolumn{3}{|c|}{ Run time from temp. change } & $\begin{array}{c}\text { Glass Dissoln. } \\
\text { Rate } \\
\end{array}$ & $\begin{array}{c}\text { Glass Dissoln. } \\
\text { Rate }\end{array}$ \\
\hline $\mathrm{pH} 8$ & (g) & (mL/day) & (days) & $(\mu \mathrm{m})$ & & & $\mathrm{Si}$ & $\mathrm{U}$ & NR-Si & NR-U \\
\hline start & 14.9620 & & 0.00 & 9.909 & 3.48465 & & $(\mathrm{ppb})$ & $(\mathrm{ppb})$ & $\mathrm{mol} / \mathrm{m}^{\wedge} 2 / \mathrm{sec}$ & $\mathrm{mol} / \mathrm{m}^{\wedge} 2 / \mathrm{sec}$ \\
\hline PGL-40-2 & 14.9609 & 14.41 & 27.14 & 9.908 & 3.48449 & 27.14 & $7.45 \mathrm{E}+03$ & 0.04146 & $9.83 \mathrm{E}-12$ & $4.462 \mathrm{E}-12$ \\
\hline PGL-40-3 & 14.9607 & 13.81 & 33.18 & 9.908 & 3.48445 & 33.18 & $6.86 \mathrm{E}+03$ & 0.02834 & $8.67 \mathrm{E}-12$ & $2.923 \mathrm{E}-12$ \\
\hline PGL-40-4 & 14.9606 & 14.10 & 35.13 & 9.908 & 3.48444 & 35.13 & $1.13 \mathrm{E}+04$ & 0.03244 & $1.46 \mathrm{E}-11$ & $3.416 \mathrm{E}-12$ \\
\hline PGL-60-2 & 14.9596 & 13.25 & 48.58 & 9.908 & 3.48427 & 13.35 & $1.63 \mathrm{E}+04$ & 0.05751 & $1.98 \mathrm{E}-11$ & $5.691 \mathrm{E}-12$ \\
\hline PGL-60-3 & 14.9591 & 14.45 & 56.47 & 9.908 & 3.48420 & 21.24 & $1.17 \mathrm{E}+04$ & 0.06320 & $1.55 \mathrm{E}-11$ & $6.821 \mathrm{E}-12$ \\
\hline PGL-80-2 & 14.9524 & 14.04 & 96.49 & 9.906 & 3.48316 & 32.54 & $3.26 \mathrm{E}+04$ & 0.21840 & $4.19 \mathrm{E}-11$ & $2.291 \mathrm{E}-11$ \\
\hline \multicolumn{11}{|c|}{ Pre-Reactor Cell - U Dissolution Rates (using $\mathbf{N}_{w}$ values from Appendix 6) } \\
\hline & $\begin{array}{l}\text { Mass of Pre- } \\
\text { Reactor Glass }\end{array}$ & $\begin{array}{l}\text { Flow } \\
\text { Rate }\end{array}$ & $\begin{array}{l}\text { Run time from } \\
\text { day } 1\end{array}$ & $\begin{array}{c}\text { Particle } \\
\text { Diameter }\end{array}$ & $\begin{array}{l}\text { Surf. } \\
\text { Area }\end{array}$ & \multicolumn{3}{|c|}{ Run time from temp. change } & $\begin{array}{c}\text { Glass Dissoln. } \\
\text { Rate }\end{array}$ & $\begin{array}{c}\text { Glass Dissoln. } \\
\text { Rate }\end{array}$ \\
\hline $\mathrm{pH} 8$ & $(\mathrm{~g})$ & (mL/day) & (days) & $(\mu \mathrm{m})$ & (sq. m) & & $\mathrm{Si}$ & $\mathrm{U}$ & NR-Si & NR-U \\
\hline start & 14.9620 & & 0.00 & 9.909 & 3.48465 & & $(\mathrm{ppb})$ & $(\mathrm{ppb})$ & $\mathrm{mol} / \mathrm{m}^{\wedge} 2 / \mathrm{sec}$ & $\mathrm{mol} / \mathrm{m}^{\wedge} 2 / \mathrm{sec}$ \\
\hline RGL-40-5 & 14.9607 & 14.41 & 26.62 & 9.908 & 3.48444 & 27.14 & $9.58 \mathrm{E}+03$ & 0.03274 & $1.26 \mathrm{E}-11$ & $3.523 \mathrm{E}-12$ \\
\hline RGL-40-6 & 14.9605 & 13.81 & 30.56 & 9.908 & 3.48442 & 33.18 & $8.42 \mathrm{E}+03$ & 0.03111 & $1.06 \mathrm{E}-11$ & $3.209 \mathrm{E}-12$ \\
\hline RGL-40-7 & 14.9603 & 14.10 & 34.45 & 9.908 & 3.48439 & 35.13 & $7.87 \mathrm{E}+03$ & 0.02895 & $1.02 \mathrm{E}-11$ & $3.049 \mathrm{E}-12$ \\
\hline RGL-60-2 & 14.9591 & 13.25 & 47.56 & 9.908 & 3.48420 & 13.35 & $1.98 \mathrm{E}+04$ & 0.05539 & $2.40 \mathrm{E}-11$ & $5.482 \mathrm{E}-12$ \\
\hline RGL-60-3 & 14.9586 & 14.45 & 55.40 & 9.908 & 3.48412 & 21.24 & $1.20 \mathrm{E}+04$ & 0.05880 & $1.59 \mathrm{E}-11$ & $6.346 \mathrm{E}-12$ \\
\hline RGL-80-1 & 14.9541 & 16.22 & 75.46 & 9.907 & 3.48343 & 14.52 & $3.79 \mathrm{E}+04$ & 0.17492 & $5.63 \mathrm{E}-11$ & $2.120 \mathrm{E}-11$ \\
\hline RGL-80-2 & 14.9538 & 16.22 & 76.42 & 9.907 & 3.48338 & 14.52 & $5.16 \mathrm{E}+04$ & 0.18025 & $7.67 \mathrm{E}-11$ & $2.184 \mathrm{E}-11$ \\
\hline RGL-80-3 & 14.9536 & 16.22 & 77.44 & 9.907 & 3.48335 & 14.52 & $3.46 \mathrm{E}+04$ & 0.18654 & $5.14 \mathrm{E}-11$ & $2.261 \mathrm{E}-11$ \\
\hline
\end{tabular}


Melt Glass Reactor Cell - U Dissolution Rates (using $S_{w}$ values from Appendix 6)

\begin{tabular}{|c|c|c|c|c|c|c|c|c|c|c|}
\hline pH 8 & $\begin{array}{l}\text { Mass of Pre- } \\
\text { Reactor Glass } \\
\text { (g) }\end{array}$ & $\begin{array}{l}\text { Flow } \\
\text { Rate } \\
\text { (mL/day) }\end{array}$ & $\begin{array}{l}\text { Run time from } \\
\text { day } 1 \\
\text { (days) }\end{array}$ & $\begin{array}{l}\text { Diameter } \\
\qquad(\mu \mathrm{m})\end{array}$ & $\begin{array}{l}\text { Surf. } \\
\text { Area } \\
\text { (sq. m) }\end{array}$ & Run time $\mathrm{f}$ & $\begin{array}{l}\text { np. change } \\
\text { Si (est.) }\end{array}$ & & $\begin{array}{l}\mathrm{pH} \text { at } \mathrm{T} \\
\text { estimated }\end{array}$ & $\begin{array}{c}\text { Glass Dissoln. } \\
\text { Rate } \\
\text { NR-U }\end{array}$ \\
\hline start & 1.08010 & & 0 & 7.77262 & 0.3207 & & (ppb) & & & $\mathrm{mol} / \mathrm{m}^{\wedge} 2 / \mathrm{sec}$ \\
\hline RGL-40-5 & 1.08005 & 13.34 & 26.62 & 7.77252 & 0.3207 & 27.14 & 350 & 7.80 & $1.436 \mathrm{E}-06$ & $1.817 \mathrm{E}-12$ \\
\hline RGL-40-6 & 1.08004 & 13.57 & 30.56 & 7.77248 & 0.3207 & 33.18 & 700 & 7.80 & $2.921 \mathrm{E}-06$ & $2.641 \mathrm{E}-12$ \\
\hline RGL-40-7 & 1.08003 & 13.49 & 34.45 & 7.77246 & 0.3207 & 35.13 & 450 & 7.80 & $1.867 \mathrm{E}-06$ & $2.132 \mathrm{E}-12$ \\
\hline RGL-60-2 & 1.07996 & 13.21 & 47.56 & 7.77228 & 0.3207 & 13.35 & 1200 & 7.76 & 4.874E-06 & $6.386 \mathrm{E}-12$ \\
\hline RGL-60-3 & 1.07989 & 13.36 & 55.4 & 7.77213 & 0.3206 & 21.24 & 1700 & 7.76 & $6.984 \mathrm{E}-06$ & $8.081 \mathrm{E}-12$ \\
\hline RGL-80-1 & 1.07957 & 12.91 & 75.46 & 7.77136 & 0.3206 & 14.52 & 3400 & 7.87 & $1.350 \mathrm{E}-05$ & $1.658 \mathrm{E}-11$ \\
\hline RGL-80-2 & 1.07956 & 14.71 & 76.42 & 7.77132 & 0.3206 & 15.52 & 3400 & 7.87 & $1.538 \mathrm{E}-05$ & $1.847 \mathrm{E}-11$ \\
\hline RGL-80-3 & 1.07954 & 13.85 & 77.44 & 7.77128 & 0.3206 & 16.52 & 3200 & 7.87 & $1.363 \mathrm{E}-05$ & $1.644 \mathrm{E}-11$ \\
\hline$\%$ loss & 0.0504 & & & & & & & & & \\
\hline
\end{tabular}

